\title{
A Waste of Shame: \\ The Heroics of Marriage in \\ English Renaissance Tragedy
}

"The Stage is more beholding to Love, then the Life of Man," Francis Bacon asserts in a typically bald and direct observation added to his essay "Of Love" in I625. "For as to the Stage," he continues, "Love is ever matter of Comedies, and now and then of Tragedies: But in Life, it doth much mischiefe: Sometimes like a Syren; Sometimes like a Fury. . . . For whosoever esteemeth too much of Amorous Affection, quitteth both Riches and Wisedome. . . . They doe best, who, if they cannot but admit Love, yet make it keepe Quarter: And sever it wholly, from their serious Affaires, and Actions of life." 1 Connecting a contemptuous view of erotic love as destructive and frivolous with a negative view of the stage as illusory, by implication properly divorced, like love, from "the serious affairs and actions of life," Bacon conjoins two characteristic Renaissance conceptions of sexuality and the the-

I. Sir Francis Bacon, "Of Love," in his The Essayes or Counsels, Civill and Moral, ed. with introduction and commentary by Michael Kiernan (Cambridge, Mass.: Harvard University Press, 1985), pp. 3I-33. As Kiernan explains (pp. vii, xix), thirteen printed editions of The Essayes were published during Bacon's lifetime, and he continued to revise them for almost thirty years, from I 597 to I625. "Of Love" was first published in I6I2, although the passage quoted is from the I625 edition, the last to appear in Bacon's lifetime. Though the second and third sections I have quoted (indicated by ellipses) received little revision, the opening part of the passage $(3-24$, p. $3 \mathrm{I})$ has been substantially revised and augmented. The original read as follows: "Love is the argument alwaies of Comedies, and many times of Tragedies. Which sheweth well, that it is a passion generally light, and sometimes extreme." Inter- 


\section{The Expense of Spirit}

ater. ${ }^{2}$ But in remarking on the relative frequency with which love is represented in comedies ("ever"-i.e., always) and in tragedies ("now and then"), the brilliant observer of actuality has uncharacteristically erred. The history of English Renaissance drama shows that by the time Bacon revised his essay to include its analogies among love, life, and the stage, eros, with increasing and discernible frequency, had in fact become the subject of tragedy. The opening arguments in his case against love confirm that Bacon, like Renaissance literary theorists, would find eros utterly inadequate to the serious action and heroic endeavor proper to the tragic form: "You may observe, that amongst all the great and worthy Persons, (whereof the memory remaineth, either Ancient or Recent) there is not One, that hath beene transported, to the mad degree of Love: which shewes that great Spirits, and great Businesse doe keepe out this weake Passion. "3 Yet in Jacobean England not only the public lives, but the sexual lives of "great Spirits" are commanding the attention of tragic playwrights, and with growing frequency eros is equated with the "great Businesse" that generates a tragic action and assumes the center of the stage. ${ }^{4}$

Bacon's observations in fact correspond accurately to the ori-

estingly, Bacon's change in emphasis from "many times of Tragedies" to the later "now and then of Tragedies," reflecting an increased desire to underscore the unsuitability of love as a tragic subject, is precisely what makes his observation wrong.

2. As Jonas Barish points out in The Antitheatrical Prejudice (Berkeley: University of California Press, I98I), p. 66, "outbursts of antitheatrical sentiment tend to coincide with the flourishing of the theater itself." See especially his chaps. 4, 5, and 6 for accounts of antitheatricalism in the Renaissance.

3. Bacon, pp. 3I-32. Bacon does go on to concede, "You must except, neverthelesse, Marcus Antonius the halfe Partner of the Empire of Rome; and Appius Claudius the Decemvir, and Law-giver: Whereof the former, was indeed a Voluptuous Man, and Inordinate; but the latter, was an Austere, and wise man: And therefore it seemes (though rarely) that Love can finde entrance, not only into an open Heart; but also into a Heart well fortified; if watch be not well kept."

4. See Madeleine Doran, Endeavors of Art: A Study of Form in Elizabethan Drama (Madison: University of Wisconsin Press, I954), pp. IO5-II, for the best account of traditional theories of tragedy and comedy in the sixteenth century. These stem primarily from two essays: the first, "De tragoedia et comoedia," is attributed to the fourth-century grammarian Donatus; and the second, also by an early grammarian, Diomedes, appears in a miscellaneous 


\section{Heroics of Marriage in Renaissance Tragedy}

gins, rather than the development, of English tragedy; as such their anachronistic quality recalls the extraordinary changes that that development comprised. English Renaissance tragedy can be characterized throughout its career by a relentless scrutiny of heroic energy; but that interrogation includes a major alteration in the conception of the heroic. Rooted in the connection between tragedy and history, the Elizabethan conception that Bacon shares focuses on a heroism of public action, emphasizing the protagonist's will to power. ${ }^{5}$ Centered on political and military struggles, tragic action consigns women, eros, and sexuality to the periphery of its concerns. In striking contrast, Jacobean plays emphasize a heroism of personal endurance, creating tragedies of private life that often focus on the consequences of corrupt or unorthodox sexuality in a dark and narrow world increasingly devoid of possibility. The prominence of women as tragic heroes and/or of eros as a tragic subject increases remarkably in Jacobean plays.

collection of grammatical treatises published in I478. Doran argues that these standard accounts of the forms were widely familiar and accessible. Although narrow, schematic, and notoriously inadequate as explanations of the drama that in fact burgeoned in England, the grammarians' treatises continued to hold sway in the sixteenth century, when, as even Sidney's Defense makes clear, there was no well-worked-out theory or "critical treatment" of the English drama. Doran demonstrates (pp. I07-8) that, reversing the probable origins of the forms, the grammarians' theories emerge in contrast to comic theory and center on the relative status of the persons ("leaders, heroes, kings"), the subject (tragedy: "conflicts, exiles; violent death" vs. comedy: "love affairs and the seizure of maidens"), and the ending ("a change of fortune for the worse.") Interestingly, in the Renaissance "the difference in subject was taken for granted," and theoretical disputes focused primarily on the persons and the ending proper to tragedy. See also Rosalie Colie, The Resources of Kind: Genre-Theory in the Renaissance (Berkeley: University of California Press, 1973). Colie argues for the acknowledgment of mixed genres and inclusiveness of genre theory in the Renaissance.

5. For the emergence of tragedy from history, see Doran, pp. I I 2-47; J. M. R. Margeson, The Origins of English Tragedy (Oxford: Clarendon, 1967), p. I I 7; and Martin Mueller, Children of Oedipus and Other Essays on the Imitation of Greek Tragedy, 1550-1800 (Toronto: University of Toronto Press, I980), pp. 8, I5, 20, 25, 46, 58. Mueller argues (p. I 8) that Renaissance tragedy comprises "a shift from a collective to a private vision of tragedy" and from an emphasis on the fate of the community to an emphasis on individual psychology. 


\section{The Expense of Spirit}

In the following discussion I attempt to show that, far from creating illusions divorced in emphasis and importance from "the life of man," Jacobean tragedy participates in a process of transformation in which the private life is beginning to be assigned a prestige and centrality that Bacon either refuses or fails to apprehend. ${ }^{6}$ By connecting the altering attitudes toward love and sexuality expressed in English Renaissance moral and religious writing to shifting conceptions of tragic heroism, this chapter explores the discursive conditions that make such a transformation possible. Just as they can in romantic comedy, two salient modes of conceptualizing women, love, and marriage can be identified in tragedy. The first, the dualistic, polarizing discourse that either idealizes or degrades women and eros and regards marriage as a necessary evil, often emerges in tragedy as an irreconcilable conflict between desire and purity, love and duty, and can be associated with a heroism of public action. The second, the more multifaceted sensibility specifically articulated in Protestant moral literature, retains much of the sexual skepticism of the former outlook while at the same time regarding marriage with great respect as the basis of an ordered society. It is this sensibility that grants women and eros the kind of importance that allows them to become primary subjects of a tragic action. By focusing on Othello and The Duchess of Malfi as particularly illuminating examples of this process, I demonstrate that Protestant sexual discourse takes tragic form as a fatal deconstruction of the contradictions and paradoxes inherent in the Protestant marriage ideal itself and can be associated with the private (often female) heroism of endurance.

This chapter also attempts to reassess the historical significance of these altering tragic conceptions of the prestige and centrality of women, eros, and marriage. Commentators frequently have

6. See Lawrence Stone, The Family, Sex and Marriage in England, 15001800 (New York: Harper \& Row, I 977); and Gordon J. Schochet, Patriarchalism in Political Thought: The Authoritarian Family and Political Speculation and Attitudes, Especially in Seventeenth-Century England (Oxford: Basil Blackwell, I975). Schochet argues (p. 54) that although the family was an established and frequently employed category in political philosophy prior to the seventeenth century, the family was never consciously recognized as a standard category in political argument and did not acquire an overtly important status in the centuries before the Stuart period. See also Edward Shorter, The Making of the Modern Family (New York: Basic, 1977). 


\section{Heroics of Marriage in Renaissance Tragedy}

viewed the shift in emphasis toward the erotic in Jacobean tragedy as a pessimistic diminishment, expressing a lack of confidence in public life and leading to sensationalism and the decadence of the form. ${ }^{7}$ Less concerned with moral judgment, those sympathetic to what is often termed the "tragedy of intrigue" nevertheless persist in viewing these plays as a falling-off: their insistent, exclusive emphasis on the private life, it is assumed, leaves them devoid of political significance. ${ }^{8}$ In contrast, new historicist approaches to this problem argue forcefully for the central political significance of sexuality in Jacobean tragedy. Yet these analyses tend to treat the representation of women and eros exclusively as a metaphor for what are viewed as "larger" social and political issues, perceiving the former as an allegory (often a disguise) of and for the latter, rather than regarding politics and sexuality as analogously related but distinctively important realms of experience. Thus new historicist approaches retain a hierarchical bias in which private experience remains subordinate to (i.e., less serious than) the concerns of public life. ${ }^{9}$ In contrast, I argue that Jacobean tragedies of love and

7. See, e.g., Una Ellis-Fermor, The Jacobean Drama: An Interpretation (London: Methuen, 1936); Irving Ribner, Jacobean Tragedy: The Quest for Moral Order (Methuen, 1936); Robert Ornstein, The Moral Vision of Jacobean Tragedy (Madison: University of Wisconsin Press, I960); T. B. Tomlinson, $A$ Study of Elizabethan and Jacobean Tragedy (Cambridge: Cambridge University Press, 1964); Eugene M. Waith, Ideas of Greatness: Heroic Drama in England (New York: Barnes \& Noble, I97I), pp. I4I-46; and Arthur C. Kirsch, Jacobean Dramatic Perspectives (Charlottesville: University Press of Virginia, I972).

8. See, e.g., Walter Cohen, Drama of a Nation: Public Theater in Renaissance England and Spain (Ithaca, N.Y.: Cornell University Press, I985), pp. 357-84. See also Doran, pp. I37, I 39; Margeson, p. 84; Northrop Frye, Fools of Time: Studies in Shakespearean Tragedy (Toronto: University of Toronto Press, I967), p. 6I; and Paula S. Berggren, “'Womanish' Mankind: Four Jacobean Heroines," International Journal of Women's Studies, I, no. 4 (1978), 349-62.

9. See, e.g., Stephen Orgel and Roy Strong, Inigo Jones: The Theatre of the Stuart Court, vol. I (London: Sotheby Park Bernet; Berkeley: University of California Press, I973), pp. 62-63; Arthur Marotti, “'Love Is Not Love': Elizabethan Sonnet Sequences and the Social Order," ELH, 49 (I982), 396428; Louis Adrian Montrose, "Celebration and Insinuation: Sir Philip Sidney and the Motives of Elizabethan Courtship," Renaissance Drama, N.S. 8 (1977), 3-35, and “'Shaping Fantasies': Figurations of Gender and Power in Elizabethan Culture," Representations, I (Spring I983), 6I-94; Frank 
marriage bear witness to a particular historical moment when private life was beginning to be assigned as much dignity and significance as public life and to be related analogously, rather than hierarchically, to public affairs; yet, because public and private domains were simultaneously perceived as distinct, they were consequently viewed with great anxiety as being in the process of pulling apart. In its creation of a heroism of marriage, Jacobean tragedy, like much of English Renaissance sexual discourse, attempts not only to articulate this moment of separation, but also to arrest it. Viewed as a historical process (rather than a fixed product of the conscious intentions of playwrights), tragedy can be seen to represent and mourn the failure of the endeavor to prevent social, moral, and sexual change; but in naming and giving significance to a previously unrecognized process of transformation, tragic discourse also itself participates in the dissolution of a prior system of meaning.

ii

Between approximately I620 and I630 John Donne delivered three sermons at weddings in which he meditates at length on the nature of marriage. ${ }^{10}$ Donne's position as the Dean of St. Pauls, which established the official authority of his pronouncements on moral and religious matters, would lend central importance to his views of marriage in any case; but his choice of subject matter, his

Whigham, "Sexual and Social Mobility in The Duchess of Malfi," PMLA, 100 (March I985), I67-86, esp. n. 2I, p. I 84, where Whigham argues that "the Duchess's actions should not be seen as erotic (a common male reduction of women's issues) but as political"; and Margot Heinemann, Puritanism and Theatre: Thomas Middleton and Opposition Drama under the Early Stuarts (Cambridge: Cambridge University Press, 1980), pp. 24, 46, where Heinemann argues that the increasing emphasis on private life in Jacobean tragedy represents the playwrights' attempt to escape the censor's greater concern with political issues.

IO. All quotations, identified in the text by volume, sermon, and page numbers, are from The Sermons of John Donne, ed. George R. Potter and Evelyn M. Simpson, Io vols. (Berkeley: University of California Press, I953-62). 


\section{Heroics of Marriage in Renaissance Tragedy}

mode of reasoning, and the very structure of his marriage sermons combine to give these documents a special relevance to the development of tragedy. The fact that he delivered them at weddings makes Donne's sermons startling, for in them he develops a consistent view of marriage as at best a necessary evil, an institution based in human inadequacy and characterized by its associations with death and sin. ${ }^{11}$ It is not that Donne finds nothing positive to say about marriage. It is rather that he subverts any arguments he makes about the importance of the institution by developing them in unpredictably negative ways, by undermining his praise with contradictions, or by changing the subject entirely.

Unlike that of the Puritans, Donne's style is scholastic, not only in its concentration on precise textual exegesis, but in its frame of reference, selection of issues, and citation of authority. Rather than relying, as the Puritans do, on Saint Paul and (often) the Old Testament, Donne builds his case on patristic insights, the wisdom of Tertullian, Ambrose, and Jerome. It is interesting to note his anachronistic preoccupation with celibacy. "There is no man nowe so dull, as to thynke that it is synne to marry," the reformer Heinrich Bullinger had observed confidently in I 543, dismissing the issue altogether as obsolete. ${ }^{12}$ Yet in the 1620 se find Donne still preoccupied with defending a change in sexual values long accepted in the mainstream of Protestant marital discourse. "We depart absolutely from those old Heretiks who did absolutely condemn Mariage," he declares stoutly in I627, "and wee must have leave too, (which we are alwaies loath to doe [my italics]) to depart from the rigidness of some of those blessed Fathers of the Primitive Church, who found some necessities in their times, to speak so very highly in praise of Continency and Chastity" (8.3.102). Donne's rhetorical dependence on patristic authority, as well as his belated

I I. In their edition of the sermons Potter and Simpson point out (vol. I, pp. 47-48) that many of Donne's published sermons probably are not as they were when he preached them. Most of them were delivered from notes, with the expectation that they would later be revised and polished for publication. No amount of polishing, however, would be likely to alter substantially the intense and persistent negativity about marriage that is expressed in these three sermons.

I2. Heinrich Bullinger, The golden boke of christen matrimonye, trans. Miles Coverdale, with a preface by Thomas Becon (London, I 543), chap. 3. 


\section{The Expense of Spirit}

need to join issue with celibacy in the first place, render this assertion dubious. "When men have made vows to abstain from mariage, I would they would be content to try a little longer then they doe, whether they could keep that vow or no; and when men have consecrated themselves to the service of God in his Church, I would they would be content to try a little farther then they doe, whether they could abstain or no," he remarks wistfully (3. I I.243). ${ }^{13}$ Donne's lingering, if reluctant, attachment to celibacy stems from the tacitly and subtly reiterated belief that sexual desire is evil; although this idea is present to some extent in many Protestant sermons, including those that are most idealistic about marriage, Donne's hostility toward eros differs in degree and intensity. ${ }^{14}$ Most Puritan preachers stress the dangers of sexual immoderation, even within marriage. But Donne regards desire as the inherently dangerous product of sin: "The Devil hath advan-

I3. Cf. "An Epistle to perswade a yong Gentleman to Mariage, devised by Erasmus in the behalfe of his frende," in Thomas Wilson, The Arte of Rhetorique ( 1580$)$, pp. 40-64. Erasmus goes on quite a diatribe against celibacy, asking (p. 6r), "Doe we praise so muche virginitie above all other? Why manne, there will bee neither single men, nor virgines alive, if menne leave to marrie, and mynde not procreation. Why doe you then preferre virginitie so muche . . . if it bee the undoing of all the whole worlde?" The argument is of course familiar from many sources, particularly Shakespeare's sonnets. But Erasmus is witty and vehement, clearly feeling that he must def end against the traditional prestige of celibacy: "Let the Swarmes of Monkes and Nunnes set forthe their order never so much, let them boaste and bragge their bealies full . . . yet is Wedlocke (beeying well and truely kepte) a moste holie kinde of life" (p. 52). Interestingly, by the time Donne was writing, such a defense had become completely unnecessary.

I4. Cf. Stephen Greenblatt, Renaissance Self-Fashioning: From More to Shakespeare (Chicago: University of Chicago Press, 1980), pp. 24I-52. Again Erasmus provides an interesting contrast by insisting (pp. 50-5I) that sex was instituted in Paradise before sin: "We make that filthie by our owne imagination, whiche of the owne Nature is good and godlie . . how chanceth it, that we thinke it lesse filthie to eate, to chewe, to digest, to emptie the bodie and to slepe, then it is to use carnall Copulation, suche as is lawfull and permitted?" Cf. Michaell de Montaigne, "Upon some verses of Virgil," in The Essayes, trans. John Florio (London, I603), bk. 3, pp. 508-9: "Why was the acte of generation made so naturall, so necessary and so ivst, seeing we feare to speake of it without shame, \& exclude it from our serious and reguler discourses? We pronounce boldly, to rob, to murther, to betray; and this we dare not but betweene our teeth." 


\section{Heroics of Marriage in Renaissance Tragedy}

tages enow against us, in bringing men and women together" (3. I I.242).

Not surprisingly, Donne's attachment to patristic sexual values also includes an unmitigated misogyny. In the sermon preached at Sir Francis Nethersole's marriage (I6I9/20), Donne spends the majority of his time lecturing "the other sexe" on their inferiority: "that they will be content . . . to be remembred that they are the weaker vessell, and that Adam was not deceived but the woman was. . . Take it any way, and it implies a weaknesse in the woman, and an occasion of soupling her to that just estimation of herself, That she will be content to learn in silence with all subjection" (2.17.344-45). Like Vives, Donne sees women's purpose not as doing anything, performing any action ("for such vertues as may be had, and yet the possessor not the better for them, as wit, learning, eloquence, musick, memory, cunning, and such, these make her never the fitter" [2.17.346]), but rather as being chaste ("for without that, Matrimonium jurato fornicatio, Mariage is but a continuall fornication, sealed with an oath" [2. I 7.346]). ${ }^{15}$

"Mariage is but a continuall fornication, sealed with an oath." A glance at the devious way in which Donne develops his arguments about marriage, changing the subject and subverting his own praise, justifies the conclusion that this pithy reflection sums up his predominant view of that institution. That marriage should be rooted in the companionship between husband and wife, or that its organization should resemble that of the nation-state and the church, drawing together by means of analogy the family and the social and spiritual orders, are two arguments that had been developed elaborately in Protesiant sexual discourse for decades. But Donne glances at the idea of marital companionship only in order

I 5. Cf. John Louis Vives, Instruction of a christen woman, trans. Richard Hyrde, (I529; rpt. London, I557), "Of the kepyng of virginitee and chastitee": "For as for a man nedeth manye thynges, as wisdome, eloquence, knowledge of things, with remembraunce, some crafte to lyue by, Justice, Lyberalytee, lustye stomacke, and other thynges moe . . . but in a woman no manne wyll loke for eloquence, greate wytte, or prudence, or crafte to lyve by, or orderynge of the commen weale, or justice or lyberalitee: finally no man wyll loke for any other thinge of a woman, but hir honestee . . f for in a woman the honestee is in stede of all. . . . Take frome a woman hir beauty, take from hir kynred, riches comelynes, eloquence, sharpenes of witte, counnynge in hir crafte: geue hir chastitee, and thou haste geuen hir all thynges." 
to dismiss it (see 2. 17.346). And he introduces the concept of public and private domains not to relate them analogously, granting each domain its importance, but rather to subordinate one to the other in a hierarchy of relative spiritual value. In a curious twist on traditional Protestant arguments, he concedes that the family is the basis of the kingdom and the church; but, he insists, only "in regard of the publique good, God pretermits private respects," by which he means that the sole purpose of marriage is procreation and the perpetuation of society. Otherwise, "man might have done well enough in that state, so, as his solitarinesse might have been supplied with a farther creation of more men . . might not man have been abundantly rich in friends, without this addition of a woman? . . how much more conveniently might two friends live together, then a man and a woman?" (2.17.336-39).

Even more surprising than Donne's evasive dismissal of passionately valued and elaborately developed beliefs is his striking lack of interest in the relationship of marriage. As we will see, the Puritans devote abundant energy to constituting and examining this relationship, imagining in detail the probable pitfalls and possible joys of the interaction between husband and wife, and providing copious lists of roles, duties, and remedies for marital conduct. ${ }^{16}$ In contrast, Donne changes the subject of the daily drama of marriage as soon as he can. He argues that Christian marriage is distinguished not by its emphasis on companionship, but by its status as a sacred mystery. Denying that marriage is a sacrament, as every Protestant was compelled to do, Donne nevertheless succeeds in restoring its sacramental quality in the conclusion of the very paragraph containing his denial (8.3.103-4). Similarly, having stated in the same text that the purpose of a marriage sermon is to dwell upon the couple, "the parties that are to be united," he has (again by the end of the paragraph) found reasons to avoid this focus, with its emphases on individual conduct and relevance to daily life. "I shall the lesse need to apply my selfe to them, for their particular instructions, but may have leave to extend my selfe upon con-

I6. See Michel Foucault, The History of Sexuality, vol. I: An Introduction (New York: Pantheon, I978), pp. 3-17 and passim. Foucault dates from the seventeenth century what he terms (p. 22) "the great process of transforming sex into discourse." 


\section{Heroics of Marriage in Renaissance Tragedy}

siderations more general" (8.3.95-96), he says, and he moves quickly to his real-and decidedly otherworldly-concerns. The relationship, as opposed to the institution, of marriage, then, is for Donne of peripheral interest and importance.

Donne's views of marriage are articulated with the greatest concision and intensity in "A Sermon Preached At the Earl of Bridgewater's house in London at the mariage of his daughter, the Lady Mary, to the eldest sonne of the Lord Herbert of Castleiland" (I627). Most startling, particularly if one imagines being the bride or groom on such an occasion, is the text Donne chose to explore before this aristocratic gathering: "For, in the Ressurection, they Neither Mary Nor Are Given In Mariage, But Are As The Angels Of God in Heaven" (Matt. 22:30). ${ }^{17}$ After dismissing the couple, as we have seen, Donne goes on to develop a compelling case against marriage as a lesser evil, for which angels af ter the Resurrection have transcended the need: "Till then we must not look for this Angellical state, but, as in all other states and conditions of life, so in all mariages there will be some encumbrances, betwixt all maried persons, there will arise some unkindnesses, some misinterpretations: . . . Then they mary not, till then they may; then their state shall be perfect as the Angels, till then it shall not" (8.3.97). In this sermon Donne, not tacitly and implicitly but clearly and completely, attributes the inevitable, because human, inferiority of marriage to its origins in sin and death. Referring again to resurrected angels, he explains:

They shall not mary, because they shall have none of the uses of mariage; not as mariage is physicke against inordinate affections; for, every soule shall be a Consort in itselfe, and never out of tune: not as mariage is ordained for mutuall helpe of one another; for God himself shall be intirely in every soul; And what can that soul lack, that hath all God? Not as mariage is a second and a suppletory eternity, in the continuation and propagation of Chil-

I7. Cf. Luke 20:34-36: "And Jesus answering said unto them, The children of this world marry, and are given in marriage: But they which shall be accounted worthy to obtain that world, and the resurrection from the dead, neither marry, nor are given in marriage: Neither can they die any more: for they are equal unto the angels: and are the children of God, being the children of the resurrection." 


\section{The Expense of Spirit}

dren; for they shall have the first Eternity, individuall eternity in themselves. Therefore does S. Luke assigne that reason why they shall not mary, Because they cannot $d y$.

[8.3.99]

In this extraordinary passage Donne one by one discards the traditional purposes of marriage articulated in the Elizabethan Book of Common Prayer in I 549: the legitimation of desire, the procreation of children, and mutual companionship. The best one can say about marriage, it seems, is that in heaven it will not exist. Is this the John Donne who risked career, reputation, and solvency to marry for love? ${ }^{18}$ Actually, the connection is not surprising; to a man so passionately obsessed with the body as was Donne, sexuality must have appeared first as an overwhelming, later as a dangerous force, associated with suffering and the destruction of hopes. ${ }^{19}$ Donne's stress on desire as human inadequacy, originating in sin and leading to death, his emphasis on the inevitability of this process and the simultaneous need to transcend it ("till then we must not look for this Angellical state"), and his preoccupation with individual self-sufficiency and isolation ("for God himself shall be intirely in every soul; And what can that soul lack, that hath all God?") all clarify the tragic nature of his conception of eros and marriage and its consequent relevance to the representation of sexuality in Renaissance drama. ${ }^{20}$

Earlier I observed that the sexual values Donne expresses in the I620s were anachronistic in their departure from what had been for decades accepted Protestant emphases and concerns. ${ }^{21}$ The dis-

I 8. See John Carey, John Donne: Life, Mind and Art (London: Faber \& Faber, I98I), pp. 7I-76, for a discussion of Donne's marriage.

19. Donne's special preoccupation with the resurrection of the body is well known. A good example of his vivid imagining of the body's destiny in his marriage sermons appears in 8.3.98: "But the Resurrection of the Body is discernible by no other light, but that of Faith, nor could be fixed by any lesse assurance then an Article of the Creed. Where be all the splinters of that Bone, which a shot hath shivered and scattered in the Ayre? Where be all the Atoms of that flesh, which a Corrasive hath eat away, or a Consumption hath breath'd, and exhal'd away from our arms, and other Limbs?"

20. The conception of desire as lack of course both precedes Donne and follows him as well, receiving a thorough theoretical formulation in twentieth-century psychoanalytic discourse, particularly in Freud and Lacan.

21. In The Development of the Family and Marriage in Europe (Cambridge: 


\section{Heroics of Marriage in Renaissance Tragedy}

placement of one sexual discourse by another is an important process to which I will return later in this chapter. Here it will suffice to observe that Donne's marriage sermons present an example of the way in which one discourse never wholly superseded another, but rather absorbed and transformed it. The public importance of Donne's position (along with his superior eloquence) can serve to recall that his sexual sensibility still counted as a significant factor in the early seventeenth-century formation of marriage. Nevertheless, the dramatic representation of that sensibility is at its most commanding and pristine in Elizabethan, rather than in Jacobean, tragedy.

In creating Tamburlaine (1587), a shocking and revolutionary play, Marlowe treats sexuality with recognizable conservatism. ${ }^{22}$ As is well known, one of Marlowe's brilliant innovations consists in endowing his warrior-hero with an aesthetic dimension, which adds to the complexity of his character; Tamburlaine's superb eloquence and sensitivity to beauty and desire are what prevent him from becoming a mindless and mediocre gangster. As Eugene Waith has pointed out, "the inclusion in [Tamburlaine's] nature of the capacity to love is a characteristic Renaissance addition to the classical model of the Herculean hero." 23 Unlike many Renaissance portrayals of soldiers, Tamburlaine does not at first appear obsessively misogynistic. As many critics have observed, the slaughter of the Damascus virgins (I. S.I $)^{24}$ is among the hero's most heinous deeds; but in his personal relation with his love, Zenocrate, Tamburlaine is caught up in adoration, rather than in active hatred, of eros:

Zenocrate, the loveliest maid alive,

Fairer than rocks of pearl and precious stone,

Cambridge University Press, 1983), Jack Goody traces the origins of Protestant sexual ideology back far beyond the Reformation. As I explain later in this chapter, however, I am interested in the present study not so much in the origins of these values as in the way they were grouped together and the degree to which they were emphasized in Tudor and Stuart England.

22. Cf. G. K. Hunter, "The Beginnings of Elizabethan Drama: Revolution and Continuity," Renaissance Drama, N.S. 17 (1986), 29-52.

23. Eugene M. Waith, "Tamburlaine," in Marlowe: A Collection of Critical Essays, ed. Clifford Leech (Englewood Cliffs, N.J.: Prentice-Hall, I964), p. 77.

24. All Tamburlaine references identified in the text by part, act, scene, and 


\section{The Expense of Spirit}

The only paragon of Tamburlaine, Whose eyes are brighter than the lamps of heaven, And speech more pleasant than sweet harmony!

[I.3.3.II7-2I]

It is true that he wins Zenocrate by kidnapping and raping her, a little-noticed fact that associates him with Truewit in Epicoene. ${ }^{25}$ Unlike Ben Jonson, Marlowe recognizes that this method of courtship might be considered problematic; like Ben Jonson, however, he decides that women would probably have liked it and that Zenocrate must have been pleased. Marlowe confronts the situation by having one of Zenocrate's courtiers, Agydas, bring up the awful event. Agydas, who cannot understand her complaisance, receives the following response from the kidnapped, raped princess:

Agyd. 'Tis more than pity such a heavenly face

Should by heart's sorrow wax so wan and pale, When your offensive rape by Tamburlaine, (Which of your whole displeasures should be most), Hath seemed to be digested long ago.

Zenoc. Although it be digested long ago, As his exceeding favors have deserved, And might content the Queen of heaven, as well As it hath changed my first conceived disdain.

[I.3.2.5-I2]

Zenocrate's acceptance of her rape, then, comprises a revision of past disdain. It is not surprising that Tamburlaine's worship of Zenocrate should rest on a foundation of hostility and violence: as is shown repeatedly throughout this book, whatever may be the relative emphasis of each component, the extreme elements coex-

line numbers, are to Drama of the English Renaissance, vol. I: The Tudor Period ed. Russell A. Fraser and Norman Rabkin (New York: Macmillan, I976), pp. 207-6I.

25. Although it may very well be remarked upon somewhere, I have not yet encountered any discussion of the fact that Tamburlaine "wins" Zenocrate by raping her. In contrast, most scholars, like Joel Altman in The Tudor Play of Mind: Rhetorical Inquiry and the Development of Elizabethan Drama (Berkeley: University of California Press, I978), p. 329, emphasize Tamburlaine as "a tender suitor" to Zenocrate. 


\section{Heroics of Marriage in Renaissance Tragedy}

ist, forming an intractable partnership in a dualizing mentality that either degrades women and eros on the one hand or idealizes them on the other. ${ }^{26}$ In Tamburlaine we can witness this sensibility in the dramatic process of its formation and can perceive its connection with tragic heroism.

Tamburlaine comes to terms with his sexual desire in the only soliloquy - the one private moment-in either part of the play (I. 5. I. I00-I90). Like Donne, Marlowe makes a very clear distinction between private and public domains. Indeed, Tamburlaine's problem with eros consists in his need to reconcile what he perceives as conflicting claims: the dramatic conflict is construed in terms of an inevitable antagonism between love and duty. Specifically, when Zenocrate begs Tamburlaine to refrain from savaging her country and murdering her father, he agrees to save her father but immediately refuses to call off his slaughter and conquest of the remaining territory and population, explaining, "Were Egypt Jove's own Land, / Yet would I with my sword make Jove to stoop" (I.4.4.78-79). In his later soliloquy, however, Tamburlaine acknowledges for the first and only time in his career that he has experienced some conflict about this situation:

A doubtful battle with my tempted thoughts For Egypt's freedom, and the Soldan's life; His life that so consumes Zenocrate, Whose sorrows lay more siege unto my soul, Than all my army to Damascus' walls:

And neither Persia's sovereign, nor the Turk Troubled my senses with conceit of foil So much by much as doth Zenocrate.

$$
\text { [I.5.I. I 52-58] }
$$

In his love for Zenocrate, then, Tamburlaine recognizes the dangerous potential for the def eat of his heroic military ambitions. His

26. Cf. Theseus to Hippolyta in Act I, Scene I, of A Midsummer Night's Dream (11.I7-I8): "I wooed thee with my sword / And won thy love doing thee injuries," in the edition by Louis B. Wright and Virginia A. LaMar, Folger Library General Reader's Shakespeare (New York: Washington Square, I958); and Madelon Gohlke, “'I wooed thee with my sword': Shakespeare's Tragic Paradigms," in Representing Shakespeare: New Psychoanalytic Essays, ed. Murray M. Schwartz and Coppélia Kahn (Baltimore, Md.: Johns Hopkins University Press, I980), pp. I70-87. 


\section{The Expense of Spirit}

immediate, defensive reaction is to abstract from the individual and personal, to move rhetorically, as Donne does, to "considerations more general." "What is beauty, saith my sufferings then?" (I.3.I.I60), he ponders, setting up the problem in broad aesthetic terms in an effort to find a "solution" to his potentially disruptive love for his wife. In a second variation on this movement, the warrior who conquers the world through his transforming eloquence acknowledges in one uncharacteristically vulnerable moment the inexpressibility of beauty ("One thought, one grace, one wonder, at the least, / Which into words no virtue can digest" [I.5.I. I72-73]); yet he retreats immediately from the possible domestic consequences of this insight, stoutly declaring its inappropriateness to heroic endeavor: "But how unseemly is it for my sex, / My discipline of arms and chivalry, / My nature, and the terror of my name, / To harbor thoughts effeminate and faint!" (I.5. I. 174-77). Tamburlaine's solution to the dilemma he perceives is to bring beauty into the service of heroism by the repression of desire: "And every warrior that is rapt with love / Of fame, of valor, and of victory, / Must needs have beauty beat on his conceits: / I thus conceiving and subduing both . . ." (I. 5. I. I 80$83)$. It is the same solution proposed by Bacon with brittle and prosaic force: "They doe best, who, if they cannot but admit Love, yet make it keepe Quarter." Tamburlaine is able to conclude his soliloquy by returning to the-now psychologically unimpededissue of military glory.

Tamburlaine's repression of sexuality takes the form not of total denial (he is "conceiving and subduing" both), but of the segregation of eros into a separate and unequal realm. It is the solution of the medieval chivalric warrior-hero, the knight. ${ }^{27}$ The effects of such a procedure are strikingly evident in Marlowe's conception of Zenocrate. Along with enhancing Tamburlaine's status by loving him and helping to define and sharpen the nature of his heroism by presenting a potentially opposing psychological principle that must be overcome, Zenocrate's other function in the play (stemming from those already mentioned) is to add a moral dimension completely absent in the hero himself that at least partially qualifies his magnificence. As Tamburlaine's slaughters increase and multi-

27. Cf. Waith, Ideas of Greatness, p. I48. 


\section{Heroics of Marriage in Renaissance Tragedy}

ply throughout Parts I and II (including the murder of one of his own sons, who, like his mother, dislikes carnage), Zenocrate's antiwar, anticruelty sentiments assume more rhetorical conviction in the play (e.g., in II.I.3). Yet-and this is the crucial pointwhile she adds a moral and symbolic emphasis to the play, affecting its tone, Zenocrate has no dramatic power. She is incapable of engendering any action. ${ }^{28}$ She is unable to deter Tamburlaine from undertaking the bloody siege of Egypt or Damascus, a failure to restrain her husband that continues into the second part of the play. Just as in Donne's marriage sermons eros and women become peripheral, removed from the enactment of serious concerns, so in Tamburlaine the nature of the hero's repression of sexual desire ensures that Zenocrate's values and the feelings she engenders will remain crucial but marginal; symbolically powerful but dramatically ineffectual, lame. Thus Zenocrate functions not as a dramatic subject, generating action, but as an object of Tamburlaine's desire and contemplation; consequently, her role is a static and decorative one, to "sit up, and rest thee like a lovely queen" (II. I.3. I6). Tamburlaine's tendency to aestheticize Zenocrate, to construe her as a beautiful object, is evident from a very early point in the play (e.g., I.3.3.II8-2I); that her final appearance in Part II is as a portrait decorating the coffin that contains her corpse-no matter how bizarre-merely constitutes the final step in Tamburlaine's project of preserving her permanently by rendering her immobile, freezing her in time.

Tamburlaine's idealization of Zenocrate therefore becomes a devious tribute: it is precisely because she is so powerful that she must be rendered static, inert. But the play makes clear that the constituting of Zenocrate as a monument is both necessary and heroic. For it is Zenocrate (or Tamburlaine's conception of her, which, I am arguing, is the same thing) who brings death into Tamburlaine's world and all his woe. As we have seen, Tamburlaine's desire for Zenocrate causes his only moment of internal conflict in the play. It is perfectly clear to him, in contrast, that he should murder his weakling son. And despite the fatal havoc Tam-

28. For contrasting views of Zenocrate's function and effectiveness in the play, cf. Altman, esp. pp. 333-36; and Richard A. Martin, "Marlowe's Tamburlaine and the Language of Romance," PMLA, 93 (March I978), 248-64. 


\section{The Expense of Spirit}

burlaine wreaks upon the world, the death of Zenocrate becomes his first actual experience (i.e., recognition) of mortality, introducing the final movement of Part II, in which the hero faces his only defeat in the form of his own death. It should be stressed that in examining Zenocrate's role in Tamburlaine's destiny, I am not arguing in terms of moral sympathy; as we have seen, Zenocrate's presence in the play symbolically enhances the hero and commands a significant quotient of sympathy, as well as respect. My concern, however, is with modes of conceptualization and the formation of belief, discernible not in terms of audience response but in terms of dramatic structure. Seen from this vantage point, Zenocrate's dramatic (as distinct from her symbolic) role is to oppose Tamburlaine's heroism and present a prologue to his doom. Like Donne constructing a marriage sermon, Marlowe constructing a tragic action construes the relationship between sexuality and death as one of (symptomatic) cause and (inevitable) effect, requiring heroic resistance in order to be transcended and overcome. ${ }^{29}$

iii

I hope by now it is apparent that a sensibility which views the nearly absolute repression of desire as necessary for the fulfillment of social and political obligation, requiring that eros be severed from the "serious affairs and actions of life," precludes the possibility of love as the central subject of tragedy in the Renaissance and entails by definition a dissociation between heroism and the private life. Marlowe's Dido, Queen of Carthage, probably written with Thomas Nashe in the same year as Tamburlaine (c. I 587), presents a final illustration of this point.

As Renaissance poets adapted it from Virgil, the legend of Dido and Aeneas is the classic Western allegory of civilization and its discontents. The hero's repression of erotic passion in pious, if sorrowful, submission to public duty and obligation creates the

29. Cf. Gohlke; and Madelon [Gohlke] Sprengnether, "Annihilating Intimacy in Coriolanus," in Women in the Middle Ages and the Renaissance: Literary and Historical Perspectives, ed. Mary Beth Rose (Syracuse, N.Y.: Syracuse University Press, I986), pp. 89-II I. See also my analysis of Lyly's heroes in Chapter I. 


\section{Heroics of Marriage in Renaissance Tragedy}

female martyr to love. ${ }^{30}$ During the Renaissance, however commentators viewed Dido, Aeneas was a favorite hero, adding an inward moral and religious dimension to the Homeric military drive toward conquest and glory. ${ }^{31}$ Thus it becomes particularly interesting that, in their attempt to represent the Dido legend as tragic, Marlowe and Nashe succeed only in rendering it degrading and ridiculous. Their conflicted Aeneas is weak, self-pitying, and ambivalent (2.I; 5.I);32 their Dido, imperious, fickle, and capricious (4.4). Neither is courageous; both are the pettiest of liars (e.g., 3.4 and 4.4). The characters and subplots Marlowe and Nashe add also function to subvert the dignity of the principal characters and undermine the importance of their love. For example, the loyal Anna, pursuing Dido's disappointed suitor, Iarbas, is transformed to Dido's rival in love; and the playwrights include comic scenes that steal the show by reminding the audience of the predominantly grotesque and anarchic properties of desire. Providing a gloss on the humiliating relationship of Dido and Aeneas, Act 4 ends when a withered crone falls in love with a boy (Cupid, of course, disguised as Aeneas's son Ascanius). "My veins are wither'd and my sinews dry; / Why do I think of love, now I should die?" she moralizes (4.4.33-34). The play concludes with the triple suicide of Dido, Anna, and Iarbas, detracting from the potentially noble and traditionally solitary passion of the queen and focusing instead on the self-destructive communal disasters engendered by sexual desire.

Thus while Dido, Queen of Carthage includes some of the characteristically idealizing love themes (e.g., transformation and selfsacrifice), Marlowe and Nashe simply cannot take these issues se-

30. See D. C. Allen, "Marlowe's Dido and the Tradition," in Essays on Shakespeare and Elizabethan Drama in Honour of Hardin Craig, ed. Richard Hosley (Columbia: University of Missouri Press, I962), pp. 55-68; and Mueller, esp. pp. 230-48. Mueller points out (p. 233) that in Virgil, "the tragedy of Dido is based on a separation of public and private values that is unknown in Greek tragedy."

31. See Reuben A. Brower, Hero and Saint: Shakespeare and the GraecoRoman Heroic Tradition (New York: Oxford University Press, I971), pp. 5558 .

32. All citations and quotations identified in the text by act, scene, and line numbers, are from The Tragedie of Dido Queene of Carthage, ed. H. J. Oliver (Cambridge, Mass.: Harvard University Press, I968). 


\section{The Expense of Spirit}

riously enough to grant them the stature and centrality of a tragic subject. Just as Donne's sermons construe eros as potentially dangerous, unavoidably imperfect and humiliating, but also as irrelevant and peripheral to humanity's transcendent, heavenly destiny, so the dramatists' Dido represents love as anarchic and self-destructive, but also as frivolous and absurd. The whimsical Ovidian prologue, in which eros is introduced in the form of Jupiter's capricious dalliance with Ganymede, is by no means irrelevant, as some scholars have argued, but consistent with the representation of eros throughout the play. ${ }^{33}$ Some scholars have noticed the similarity of this play to the brittle, charming, and misogynistic comedies of Lyly, which, as we have seen, also deny the seriousness and dignity of desire. ${ }^{34}$ Far from being a critique of heroic energy, then, Marlowe's Dido avoids any treatment of the heroic and clarifies instead the dissociation between public heroism and private life.

Although sexual desire in Tamburlaine is idealized and exalted, it is also rendered dramatically inert, consigned to subordinate status, and viewed as potentially destructive of public enterprise. As Eugene Waith observes, one of the major properties of Tamburlaine's heroism, like that of Castiglione's ideal courtier and the chivalric warrior-knight, is his ability to treat "beauty as the handmaid of valour." Waith argues that in Tamburlaine Marlowe provides "the definition of a hero." Transcending his Scythian-shepherd origins, Tamburlaine, a type of Hercules, adds to "the intrinsic kingliness of the hero, associated with the ideal of freedom" a magnificent physical stature, towering wrath and cruelty, inflexible will, incomparable, transforming rhetorical power, delicate, idealizing aesthetic sensitivity conjoined with the ability to love, and uncompromising valor, ambition, and pride: "he does not belong entirely to either earth or heaven." While stressing Tamburlaine's "incorporeal spirit," Waith does not deny either "the tensions between his egotism and altruism, his cruelties and benefactions, his human limitations and his divine potentialities"

33. See, e.g., The Tragedie of Dido Queene of Carthage, p. 4, nn. I-2. Brower comments at length (pp. I20-4I) on the Elizabethan use of Ovidian material specifically as a denial of the heroic mode.

34. Cf. Allen, p. 64; and my analysis of Lyly's plays, above. 


\section{Heroics of Marriage in Renaissance Tragedy}

or his enactment of the tragic hero's characteristic "collaboration with death and fate in the destruction of his physical being." 35

Tamburlaine, then, is the complete hero of Renaissance humanist idealism, combining military proficiency with rhetorical ability and devoting himself to public action. Indeed, his lowly origins, conjoined with his transforming eloquence, connect him optimistically and confidently with the increasing social mobility of the sixteenth century, when education and verbal skill were rapidly becoming as important to advancement in the bureaucratic nationstate as aristocratic birth and military competence. ${ }^{36}$ Yet Tamburlaine's heroism, like Elizabethan social mobility, contains its own implicit obsolescence. Although they remained greatly indebted to Tamburlaine, exploiting and refining many aspects of the play, English Renaissance tragic dramatists-including Marlowe himself in subsequent plays-never sought to duplicate the conjunction of military competence with the ability to engage and suppress the private life that constitutes Tamburlaine's greatness. ${ }^{37}$ The happy combination of transcending birth, demonstrating prowess, and cultivating repression apparently seemed more appropriate to the transient figures of history-Henry $\mathrm{V}$, for example, who manages to escape the taint of his father's usurpation. In contrast, tragic playwrights increasingly insisted on the importance of the private life, weighing its fatal demands and scrutinizing the price, even the whole idea, of public success. ${ }^{38}$ Referring specifically to Chapman and Shakespeare, Reuben A. Brower describes this shift in the tragic sensibility: "Both English writers share the tendency to replace physical by moral heroism, to make

35. Waith, "Tamburlaine," pp. 78, 70, 74, and passim. See also Harry Levin, The Overreacher: A Study of Christopher Marlowe (Cambridge, Mass.: Harvard University Press, I952). For the complicity of the tragic hero with death, see Frye, esp. pp. 3-9, 33, 39.

36. See Frank Whigham, Ambition and Privilege: The Social Tropes of Elizabethan Courtesy Theory (Berkeley: University of California Press, I984), pp. I 2-I 8 and passim; Maurice Keen, Chivalry (New Haven, Conn.: Yale University Press, I984), esp. pp. 238-53; and Lawrence Stone, "Social Mobility in England, I 500-I700," Past and Present, 33 (1966), I6-55.

37. Cf. Hunter.

38. See G. K. Hunter, "The Heroism of Hamlet," in Hamlet, Stratfordupon-Avon Studies, no. 5, ed. J. R. Brown and B. Harris (London: Edward Arnold, I963), pp. 90-I09, esp. p. 96. 
the great battle the inner one of the soul or of reason against passion, to regard the heroic career as humane education or as a tragic failure to achieve it. The increased self-consciousness of Chapman's heroes as compared with Homer's, their penchant for reflection and meditative analysis is equally typical of the heroes of Shakespeare. . . . This image, combining the ancient heroic ethos with the Renaissance ideal of passion governed by reason, had immense possibilities for a practising dramatist." 39 It is in the dramatists' increasing concern for "the private life of the soul," rather than horrors, madness, and revenge, that Brower locates the major influence of Seneca on Renaissance tragic heroism, 40 "a version of heroism," G. K. Hunter adds in a discussion of Hamlet, "which depends less upon acting or even upon knowing than upon being ... Hamlet represents an enormous and convulsive effort to move forward to the heroism of the individual, without abandoning the older social and religious framework of external action." 41

Transforming conceptions of tragic heroism inevitably generated a shift in emphasis in the representation of heroic qualities. Specifically, a dramatic focus on physical action and self-assertion diminished, and the exploration of heroic endurance, self-denial, and suffering increased. This shift was in turn accompanied by a greater emphasis on the private life. It is often argued that Shakespearean tragic heroes combine in their dramatic identities both action and suffering, internalized victor and victim. ${ }^{42}$ Yet scholars have also tended to polarize these conceptions of tragic action as opposed, viewing the emphasis on suffering and endurance in the latter dynamic as leading away from the idea of the heroic, which

39. Brower, pp. 80-8I.

40. Brower, p. I68. See also G. K. Hunter, "Seneca and the Elizabethans: A Case Study in 'Influence,'” pp. I 59-73, and "Seneca and English Tragedy," pp. 174-213, both in his Dramatic Identities and Cultural Tradition: Studies in Shakespeare and His Contemporaries (Liverpool: Liverpool University Press, I978); and T. S. Eliot, "Seneca in Elizabethan Translation," in his Selected Essays (London: Faber \& Faber, 1932), pp. 65-IO5.

4I. Hunter, "The Heroism of Hamlet," pp. Ios-8, italics his.

42. See, e.g., Waith, Ideas of Greatness, p. I26; Hunter, "The Heroism of Hamlet," p. IO8; and Maynard Mack, "The Jacobean Shakespeare: Some Observations on the Constructions of the Tragedies," in Modern Shakespearean Criticism: Essays on Style, Dramaturgy, and the Major Plays, ed. Alvin B. Kernan (New York: Harcourt, Brace \& World, 1970), pp. 323-50. 


\section{Heroics of Marriage in Renaissance Tragedy}

is construed in turn as the energetic pursuit of "some ideal which stretches human capacities to the utmost, whether the ideal is impossibly remote and therefore self-destructive . . . or attainable." 43 Brower, for example, constructs a dichotomy between the heroic and the "saintly"; and Eugene Waith strongly argues against the heroism of a figure like the Duchess of Malfi: "Nothing could make clearer the distinction between this play and what can properly be called heroic drama than the ironic fact that alive, the heroine is a victim, and only begins to exert a powerful influence over others after her death." ${ }^{4}$ In summary of this viewpoint, then, the logic of the increasing emphasis on private life, with its corollary focus on suffering and endurance, inevitably leads away from tragic and heroic representation in Renaissance drama.

Although these arguments provide a partial description of a result, they do not constitute an analysis of a historical process. Once again they are based on the equation of history with political and military action, and they depend on distinguishing public from private life and privileging the former domain. As I hope to show, however, the culmination of Jacobean tragedy has to do both with changing ideas of what constitutes heroic experience and with the purpose of tragedy as a genre. In the following chapter I return to these developments, exploring their causes in sociohistorical terms. Here I am arguing that many of the most important Jacobean tragedies focusing on love and sexuality develop a new conception of heroism that depends not on an ideally imagined separation between public and private life, but on the assumption that the two domains should and must be united. Representing public and private spheres as analogous realms of experience and granting them equal significance, these plays are not concerned with conflicting allegiances between love and duty per se; they focus instead on the contradictions and paradoxes inherent in sexuality itself. In what follows I demonstrate the way in which Jacobean tragedies construct a heroics of private life, centered on the relationship of marriage. As noted above, such an endeavor is precluded by the

43. Waith, Ideas of Greatness, p. I 69. Cf. Frye, esp. pp. 3-39; and Norman Rabkin, Shakespeare and the Problem of Meaning (Chicago: University of Chicago Press, I98I), pp. 8I-89.

44. Brower, pp. 4I6-20; Waith, Ideas of Greatness, p. I46. 


\section{The Expense of Spirit}

conception of eros, women, and marriage as either idealized and transcendent or degraded and peripheral that is dramatized in Tamburlaine and Dido. The heroics of marriage requires a different sensibility for its articulation, one in which private life is viewed as central, women are perceived as active and complex, and marriage has gained in stature and prestige. That sensibility can be located precisely in Protestant (largely Puritan) sexual discourse.

Recent research on the history of marriage, the family, and sexuality has demonstrated that privacy in the modern sense was at best a newly emerging and in many cases completely unrecognized phenomenon in the Renaissance. In her studies of such peasant rituals as the charivari, for example, Natalie Davis explores the ways in which the community could exert public pressure on a married couple, articulating their views of that couple's intimacy through a cruelly mocking, but acceptable ritual. ${ }^{45}$ Lawrence Stone and Edward Shorter show that physical privacy was rare, even in the most aristocratic households, ${ }^{46}$ an argument for which literary evidence abounds: in Beaumont and Fletcher's The Maid's Tragedy, the scene at the beginning of Act 3 (1l. I-I20) in which Evadne and Amintor's wedding night is assumed to require the communal attention of the court provides one example; the account of a raucous crew surrounding the bed of a newly married couple during consummation, separated from the bride and groom only by a curtain, provides another. ${ }^{47}$

45. Natalie Zemon Davis, "The Reasons of Misrule," in her Society and Culture in Early Modern France (Stanford, Calif.: Stanford University Press, 1979), pp. 97-123, and The Return of Martin Guerre (Cambridge, Mass.: Harvard University Press, 1983), pp. 20-21.

46. See Stone, Family, Sex, and Marriage, pp. 4, 6-7, 256, 484, 605; and Shorter, pp. 39-53.

47. Francis Beaumont and John Fletcher, The Maid's Tragedy, in Stuart Plays, ed. Arthur H. Nethercot, Charles R. Baskervill, and Virgil B. Heltzel; rev. Arthur H. Nethercot (New York: Holt, Rinehart \& Winston, I97I). For an account of the raucous crew, see George Puttenham, The Arte of English Poesie, facsimile reproduction of 1906 reprint, ed. Edward Arber (Kent, Ohio: Kent State University Press, 1970), pp. 64-68. Although Puttenham relates 


\section{Heroics of Marriage in Renaissance Tragedy}

This fluid relation between public and private life, which assumes their continuity rather than their disjunction, can be construed in political terms as the incursion of authority in its attempts to regulate behavior. ${ }^{48}$ Certain Sermons or Homilies Appointed to Be Read in Churches in the Time of Queen Elizabeth clearly represents such an endeavor. The queen's abundantly expressed displeasure at her courtiers' marriages is well known; and in a similar vein of establishing the assumption of royal dominion over the intimate lives of subjects, Jonathan Goldberg tells the less familiar tale of James I interrogating his daughter about the minute details of her wedding night. ${ }^{49}$ Extending the logic behind such incidents to the modern centuries, Michel Foucault has argued that our assumptions of privacy in sexual matters constitute a collective delusion. We have, he believes, surrendered our claims to sexual autonomy to the manipulative, self-interested ideological control of the helping professions, replacing the church's confession box and monarchical scrutiny with the supervision of the social worker and the analyst's couch. ${ }^{50}$

Foucault's argument, if extreme, is trenchant and compelling. His analysis functions as an exposé, stripping away illusions and forcing acknowledgment of the hidden mechanisms of power, reg-

this story as an account of epithalamia in ancient times, asking pardon (p. 65) "of the chaste and honorable eares," he adds that the custom is "(in my simple opinion) nothing reproueable."

48. The best study of the ways in which relations of power constitute individuality in Renaissance literature is Greenblatt's Renaissance Self-Fashioning. Also see Natalie Zemon Davis, "Boundaries and the Sense of Self in Sixteenth-Century France," in Reconstructing Individualism: Autonomy, Individuality, and the Self in Western Thought, ed. Thomas C. Heller, Morton Sosna, and David E. Wellbery (Stanford, Calif.: Stanford University Press, 1986), pp. 53-63. Davis is less concerned with the incursions of authority against the individual. Indeed, she sees autonomy as a nineteenth-century value and provides a very useful discussion of the "embeddedness" of the self in the family and other social structures and networks of relationship, as well as stressing the fluid boundaries between the individual and the social body in the Renaissance. See also Jonathan Goldberg, James I and the Politics of Literature (Baltimore, Md.: Johns Hopkins University Press, 1983), pp. 86-89.

49. Goldberg, p. 107.

50. Foucault, passim. See also the discussion of René Girard in Tony Tanner, Adultery in the Novel: Contract and Transgression (Baltimore, Md.: Johns Hopkins University Press, 1979), pp. 89-9I. 


\section{The Expense of Spirit}

ulatory mechanisms of the sort that were open and acceptable in the Renaissance. The peculiarly modern cultural illusion about the individuality and independence of sexual relations, then, like the many problems of the modern family, is coincident with an ideology that, mystifying privacy, was not characteristic of the Renaissance. As Jonathan Goldberg observes: "Even as it withdrew from public life, cutting itself off from the world it once replicated, the modern family opened itself to a continual surveillance from the outside world. . . . Modern parents worry endlessly about childrearing; a whole structure of society is brought into the home in manuals and in a pervasive support system that includes doctors, psychiatrists, social scientists, therapists of all sorts, judges when children prove delinquent, teachers. . . . In this ideological structure lies the crucial difference between the modern, post-Freudian family, and the family in the seventeenth century. The family of the past did not regard its relationship to society as problematic." 51

Although the basic distinction Goldberg makes is eloquent and illuminating, an understanding of Jacobean tragedy requires that it be refined. Evidence from the drama and from Renaissance sexual discourse indicates clearly both an emerging awareness of an increased sense of conflict between the demands of public and private domains and a profoundly anxious cultural perception of that disjunction as problematic. Jacobean tragedy centering on private life can be understood as an attempt to define and articulate this process of change, as well as an endeavor to arrest it.

This dramatic attempt at the definition and control of private life finds its discursive analogue in Puritan sexual discourse. Historians have questioned the originality of the post-Reformation ideal of marriage, as well as its relevance to actual behavior. ${ }^{52}$ Although my analysis assumes a complex interrelationship between ideology and conduct, it is primarily concerned with the parallel construction of sexual values and dramatic forms; connections with the actual sexual behavior of Renaissance men and women are meant to be suggestive. Second, whereas many of the Puritan marital

5I. Goldberg, pp. $88-89$.

52. See, e.g., Goody, pp. 23-26; and Kathleen M. Davies, "Continuity and Change in Literary Advice on Marriage," in Marriage and Society: Studies in the Social History of Marriage, ed. R. B. Outhwaite (London: Europa, 198I), pp. 58-80. 


\section{Heroics of Marriage in Renaissance Tragedy}

themes may be derivative, the emphasis, elaboration, and wide distribution they receive in the Puritan tracts are completely new. Indeed, no one has questioned the existence of the Puritan view of marriage as a pervasive ideal of central importance; it is the power, popularity, and wide accessibility of this sensibility that establishes its relevance to the drama, an equally popular and accessible means of communication. ${ }^{53}$

In their ideological campaign to promote the importance of the family, the Puritans continually define the family as a private institution that is nevertheless distinguished by its connections to political and spiritual life. With urgent solemnity all the Puritans argue - indeed, insist upon - the public dignity and cosmic significance of marriage, viewing it as the arena in which salvation and damnation are determined for husband and wife. "The priuate vocations of a family, and functions appertaining thereto, are such as Christians are called unto by God, and in the exercising whereof, they may and must imploy some part of their time," declares William Gouge, not untypically. ${ }^{54}$ Although the Puritan preachers express a wider variety of views and approaches than is commonly recognized, the crucial configuration on which all their arguments depend is their careful, fervent elaboration of the ancient analogy connecting the family, society, and the spiritual realm. ${ }^{55}$ "Commonwealths I say," Alexander Niccholes declares of marriages, joining his colleagues in explaining that the husband is to the wife as the magistrate is to the subject, as Christ is to the church. ${ }^{56}$ One of the most

53. See Davies, pp. 79-80, for statistics about the frequent publication of some of the Puritan marriage tracts.

54. William Gouge, Of Domesticall Duties (London, I622), p. 17, italics his.

55. See, e.g., Gouge, pp. 2, I7, 219-20, 260-6I, 410; William Perkins, Christian Oeconomie; or, Houshold Government (London, I63I), in Workes, vol. 3, p. 669; John Dod and Robert Cleaver, A Godlie forme of householde Government (London, I 598), sig. A4; Samuell Hieron, The Sermons of Master Samuell Hieron (London, I635), p. 469; and William Whately, A Care-cloth (London, I624), p. 38. The Puritan analogies among the family, the state, and the church are discussed in William Haller and Malleville Haller, "The Puritan Art of Love," Huntington Library Quarterly, 5 (194I-42), 235-72; and in Christopher Hill, "The Spiritualization of the Household," in his Society and Puritanism in Pre-Revolutionary England (New York: Schocken, 1964), pp. 443-8I.

56. Alexander Niccholes, A Discourse of Marriage and Wiving (London, I6I5), p. I78, in Harleian Miscellany, ed. William Oldys, vol. 2 (I808-I3). 


\section{The Expense of Spirit}

resonant constructions of this critical link between public and private life occurs in Gouge's enumeration of the multiple victims created by one couples' adultery. The sin of adultery is committed against

each person in the holy Trinitie . . one's neighbour, as the partie with whom the sinne is committed ... the husband and wife of each partie ... the children borne in adulterie ... the alliance and friends of each partie (to whom the griefe and disgrace of this foule sinne reacheth) the whole family appertaining to either of them . . . the towne, citie, and nation where such vncleane birds roost (for all they lie open to the vengeance of God for this sinne) and the very Church of God (the holy seed whereof is by this sinne hindred) . . . against the parties themselues that commit this sinne, and that against their soules, bodies, name, goods, and all that appertaineth to them. ${ }^{57}$

Extending the idea of the family as a model of the church and the state, Gouge, in this vision of the inexorably escalating communal violence resulting from a single adultery, assigns a new, public significance to the actions of private individuals. The other $\mathrm{Pu}-$ ritans share Gouge's sense that the cosmic and political, as well as the individual, stakes involved in marriage are momentous indeed. Choosing "a good Wife from a bad," Niccholes warns his readers, "is to cut by a Thread, betweene the greatest Good or Evill in the World." John Dod and Robert Cleaver assert that an irresponsible father who neglects the little commonwealth of his family is nothing less than the "murtherer of their souls, and cutthroats of their salvation." 58

As these emphases on the communal consequences of individual actions and on the connections between individual choice and public responsibility indicate, the Puritans develop from their idea of the family as a model of the church and state, containing within its private sphere multiple levels of significance and possibility, a conception of marriage as a heroic endeavor. To some, marriage presents the opportunity for self-knowledge and the glory of happiness: "the very name ... should portend unto thee merryage . . f for

57. Gouge, p. 220, italics his.

58. Niccholes, p. I 56 ; Dod and Cleaver, sig. $A^{4}$. 


\section{Heroics of Marriage in Renaissance Tragedy}

marriage awaketh the understanding as out of a dream." 59 Others, more pronounced in their distrust of sexuality, view marriage as a solemn duty but happiness as a dangerous delusion. "Likely none doe meete with more crosses in marriage, or beare their crosses more vntowardly, then those that most dreame of finding it a very Paradise," remarks William Whately, the Jacobean vicar of Banbury. ${ }^{60}$ Yet whether the Puritans stress the obstacles or the rewards inherent in marriage, the crucial point becomes their consensus that this relationship constitutes the arena in which the individual can struggle and meet death or defeat, triumph or salvation: "for marriage is an adventure, for whosoever marries, adventures; he adventures his peace, his freedom, his liberty, his body; yea, and sometimes his soul too." Furthermore, undertaking this quest, "the means either to exalt on high to preferment, or cast down headlong to destruction," becomes "this one and absolutely greatest action of a man's whole life," requiring the unwavering commitment characteristic of the hero and assuming the properties of inevitable destiny: "as thereon depending the future good or evil of a man's whole after-time and days." Marriage is a perilous odyssey, a voyage on a dangerous sea, "wherein so many shipwreck for want of better knowledge and advice upon a rock." 61

Describing the perils involved in the heroic marriage and suggesting their remedies, commentators rely frequently on military metaphors of conquest and self-defense: "for it is in this action as in a strategem of war: 'Wherein he that errs can err but once, perisheth unrecoverably to all after-advice and relief" ";62 "a valiant souldier doth neuer repent of the battaile, because he meetes with strong enemies; he resolues to be conquerour, and then the more and stronger his foes, the greater his honour";63 "[domestic] au-

59. Niccholes, p. I60. Cf. Dod and Cleaver, sig. $\mathrm{K}^{3}$; Gouge, pp. 225, 227; John Wing, The Crowne Conjugall, or, The Spouse Royal (London, I632), pp. 85, 98; and Henry Smith, "A Preparative to Marriage," in The Works of Henry Smith, vol. I, ed. Thomas Fuller (Edinburgh, I 866), pp. I-40.

6o. Whately, sig. A4v.

6I. Niccholes, pp. I62, I59, I64, I59, I6I. For the absolute, unwavering nature of the tragic hero's commitment, see references in notes 42 and 43 , above.

62. Niccholes, pp. I 59-60.

63. Whately, p. 80. 


\section{The Expense of Spirit}

thoritie is like a sword, which with ouer much vsing will be blunted, and so faile to doe that seruice which otherwise it might when there is most need. A wise, graue, peaceable man, may alwayes have his sword in readiness, and that also very bright, keene, and sharpe: but he will not be very ready to plucke it out of his scabberd." 64 It should be stressed that the Puritans' use of military metaphors to construct the heroism of marriage is qualitatively different from poets' use of Petrarchan conceits that image love as the war between Venus and Mars. These tracts do not employ the vocabulary of the battle of the sexes-often frivolous, always self-defeating. Theirs is instead the language of epic endeavor, the intensely serious vocabulary of Tamburlaine the Great. But the Puritans' use of "high astounding terms" to construe marriage does not function to clarify conflicting allegiances between duty and desire, between public and private life, and to favor the former; rather, their urgent insight is that private life is public; love is a duty and marriage the conquest that must be achieved.

Indeed, the Puritans have not so much duplicated the military idiom in their idealization of marriage as absorbed and transformed it. Referring to bullying husbands, for example, Gouge observes, "Their authoritie is like a swaggerers sword, which cannot long rest in the sheath, but vpon euery small occasion is drawne forth. This frequent vse of commanding, maketh their commandements nought regarded." 65 If applied to Tamburlaine, this image of a restrained commander constitutes not praise, but a critique. The virtues required by the heroics of marriage are not those of magnificence-physical prowess and imperial will-but of the inner strength and courage required to act when necessary, but also to refrain from direct action, to suffer and endure. Husband and wife are frequently viewed as "yokefellows" in a struggle in which the inevitability of trouble must be acknowledged and prepared for: "Expectation of an enemie," warns Whately, "is halfe an arming; but suddennesse addes terriblenesse unto a crosse, and makes it insupportable."66 The well-prepared soldier-spouse of either sex

64. Gouge, p. 378.

65. Gouge, p. 378. For other uses of the heroic/military idiom in constructing marriage, see Wing, "To the Reader" and pp. 63, 74, 125-33; and Whately, pp. 25-26, 42, 46-48, 58-59, 68, 72, 74, 76-77, 80.

66. Whately, p. 74 . 


\section{Heroics of Marriage in Renaissance Tragedy}

must be armed above all with patience. With a shrewd sense of the dynamics of daily life bordering on psychological insight, Gouge explains that "if either of them be cholericke or prone to be angry on a sudden, the other must endeuour to take away all occasions of offence: and if both should be testie and hastie to wrath, when the one seeth the other first moued, the partie whose passion is not yet stirred, ought the rather to be setled and composed to all meeknesse and patience, lest, if both together be prouoked, the whole houshold be set on fire." 67 In his slightly more apocalyptic account, Whately also emphasizes the need to suffer and endure: "So must the husband and wife resolue to conquer the troubles of marriage, and vse the buckler of patience against the blowes of aduersitie, that they may conquer. . . . O, let me be strengthened with all might, according to thy glorious power, vnto all longsuffering and patience with ioyfulnesse. Lord, strengthen me against all infirme and impotent fallings of heart, against all furious and violent risings of spirit: and seeing thou hast brought me into marriage, inable mee to beare the burdens of marriage." 68 As the rhetoric of armed struggle in this context makes clear, virtuous suffering, the extreme of which is victimization, is not conceived as passive but as a kind of action, requiring perhaps above all a dynamic obedience to God: "The Lord that now doth exercise mee with these trials, will afford mee so much the more glorie in Heauen. . . . Not onely troubles suffered for righteousnesse sake, doe make the Crowne of glorie more bright and weightie, but all troubles patiently suffered, are the seede of great rewards to come. . . . O, therefore make me more obedient to thee." 69

Patience in the face of inevitable affliction; the moral prestige such affliction grants the sufferer, who is personally chosen by God to endure; obedience, humility, fortitude-the heroism of endurance has a multiplicity of sources, including Seneca and the stoics, the lives of the Catholic saints, the continuing popularity of medieval treatises on the art of dying, Patient Griselda stories, and the careers and tribulations of both Protestant and Jesuit martyrs related to Renaissance audiences. ${ }^{70}$ The eclectic background of this

67. Gouge, p. $24 \mathrm{I}$.

68. Whately, pp. 80-82.

69. Whately, pp. 83,85 .

70. See references in notes 23, 27, 3I, 35, and 37-44, above. Also see Nancy Lee Beaty, The Craft of Dying: A Study in the Literary Tradition of the ars 


\section{The Expense of Spirit}

tradition makes clear that it comprises a conception of heroism that includes both sexes among its protagonists. Yet the relevance that this construction of goodness and greatness has for women is peculiarly striking. For the terms that constitute the heroism of endurance are precisely those terms used to construct the Renaissance idealization of woman: patient suffering, mildness, humility, chastity, loyalty, and obedience. ${ }^{71}$

As Catherine Belsey has shown, in both Puritan sexual discourse and English Renaissance tragedy, women begin to emerge as subjects. Basing the identity of the subject in language and action, Belsey defines subjectivity as "the destination of meaning. . . . To be a subject is to have access to signifying practice, to identify with the 'I' of utterance and the 'I' who speaks. . . Subjects as agents act in accordance with what they are, 'work by themselves' to produce and reproduce the social formation of which they are a product." 72 Women by no means assume this status uniformly in the Puritan tracts, any more than they do in tragedy. In Niccholes's contribution to the heroics of marriage, for example, entitled "A Discourse of Marriage and Wiving" (I6I5), woman remains the unaddressed and objective other, the goal to be achieved by the hero-quester, man. Similarly, in John Wing's The Crowne Conjugall, or The Spouse Royal (1632), a rhapsodic aria, the pursuit of happiness finds its destination in "the worth of a gracious wife"; thus Wing clearly establishes happiness as a male prerogative. Ecstatically grateful, Wing does address woman, but, again as a distinct other and only to assure her that as "the weaker creature," both "fraile, and in-

moriendi in England, Yale Studies in English I75 (New Haven, Conn.: Yale University Press, 1970).

7I. For accounts of the association of female heroism with patient suffering, endurance, and martyrdom, see Marina Warner, Alone of All Her Sex: The Myth and the Cult of the Virgin Mary (New York: Random House, Vintage, I983), esp. pp. 68-78. Also see Jane Tibbetts Schulenburg, "The Heroics of Virginity: Brides of Christ and Sacrificial Mutilation," pp. 29-72, Mary Ellen Lamb, "The Countess of Pembroke and the Art of Dying," pp. 207-26, and Mary Beth Rose, "Gender, Genre, and History: Seventeenth-Century English Women and the Art of Autobiography," esp. pp. 259-67, all in Rose, Women in the Middle Ages and the Renaissance.

72. Catherine Belsey, The Subject of Tragedy: Identity and Difference in Renaissance Drama (London: Methuen, I985), pp. 5-6. 


\section{Heroics of Marriage in Renaissance Tragedy}

feriour," she should possess even greater happiness in marriage than man: "If a piece of man (a rib) could make you so rare a favor to us, our whole man must needs be a much more rich mercy to you. All this, (and much more which I could adde) is on our side, and shewes you to be more happy in us, then it is possible for us to be in you. "73

In contrast to the misogyny of Niccholes and Wing, the prominence women assume in other Protestant tracts becomes more striking. Edmund Tilney's Flower of Friendship (I 568), a dialogue clearly modeled after The Courtier, distinguishes itself from its predecessor by including women not merely as mediators, but as protagonists in the debate. Rather than concentrating solely on the need for female chastity, Gouge's Of Domesticall Duties (I622) inveighs against the sexual double standard, insisting that both partners in a marriage must remain chaste and arguing for equality of sexual desire: "Their power also ouer one another in this respect is alike." Gouge spends a virtually equal amount of time enumerating husbands' and wives' duties and responsibilities in marriage. ${ }^{74}$ Of the tracts I have studied, however, Whately's A Care-cloth (I624) treats women with the greatest interest and imagination. Whately not only gives women equal time in his considerations of marriage, but also recognizes a distinctly female point of view and attempts to enter into it. Clearly, Whately has tried to imagine what it is like to be a woman: "What if he lye thus by me groning, and tossing, many dayes, weekes, moneths, and some yeeres?" he asks, taking on the role of a dreadfully unhappy wife. "What if breeding be troublesome, so that I scarce enjoy an healthie day from conception to quickning, from quickning to trauel? What if bringing forth be so tedious and painefull, that I neuer become a mother, but by going thorow the torment of an hundred deaths in one, besides a long weakenesse after? . . . How shall I beare headach, heart-ach, back-ach, stomack-ach, retching, casting, longing, loathing, quawines, pangs, swoundings, and twentie deaths a day?"75

This imaginative apprehension of female consciousness, projected into a soliloquy, brings us very close to the capabilities of the

73. Wing, pp. I28, I29, I33, italics his.

74. Gouge, p. 2 I 9.

75. Whately, pp. 48-49. 


\section{The Expense of Spirit}

drama. Given the fact that the properties of the heroism of endurance as established in the Puritan tracts coincide with the Renaissance idealization of women, it becomes clearer why women are able to assume a place of central importance in the drama of marriage, as well as to find a voice in which distinctly female experiences can be articulated. It is, perhaps, more accurate to state that this place and voice begin to be imagined in Puritan sexual discourse, which, like the drama, is produced almost exclusively by men. ${ }^{76}$

Throughout the heroics of marriage the conceptualization of women is riddled with ironies and paradoxes that are continually inscribed but inconsistently acknowledged. Although they are everywhere present, most of these unresolved logical discrepancies center on the issue of equality between spouses and the corollary tenet of wifely obedience and subordination. As is well known, the Puritans believed in a kind of spiritual autonomy that led them to assert an equality before God between the sexes. In his discussion of marriage, for example, Calvin includes both versions of the creation story found in Genesis. ${ }^{77}$ Dod and Cleaver acknowledge that men and women will be equals in eternity, and Wing comments that "what wee read of man, or the Sonne of man, is generally to be taken, as intended of both sexes, the words (and their meaning) being as true of women, as men."78 This valued spiritual equality becomes the basis of the companionship between man and woman that the Puritans agree is fundamental to marriage. The problems come not when the preachers are formulating their vision of sexual equality, but when they turn to consider conduct, action. As we have seen, rather than dwelling exclusively on female chastity, many of them argue against the sexual double standard, with some explicitly asserting equality of rights, expec-

76. The first English play known to be by a woman is Elizabeth Cary's The Tragedy of Mariam (1603-4? published I6I3), ed. W. W. Greg (Oxford: Oxford University Press, I9I4).

77. John Calvin, "The Form and Manner of Celebrating Marriage," in his Tracts and Treatises on the Doctrine and Worship of the Church, trans. Henry Beveridge, vol. 2 (Grand Rapids, Mich.: Wm. B. Eerdmans, I958), pp. I23, I25.

78. Dod and Cleaver (rpt. London, I630), sig. K8; Wing, p. 25, italics his. See also Calvin, pp. I23-25. 


\section{Heroics of Marriage in Renaissance Tragedy}

tations, and feelings in relation to sexual desire. ${ }^{79}$ But having articulated that men and women have identical power in the realm of desire, Gouge, for example, immediately subverts this argument by declaring that the husband's power, and therefore his responsibility, are in fact greater in sexual as in other relations: "the more it appertaineth to them [i.e., husbands] to excell in vertue, and to gouerne their wiues by example." 80

Along with that of the spirit, the other conception of domestic equality that the Puritans urge, and with blithe inconsistency undermine, centers on class, status, age, and money, all areas in which, notably, private and public domains are linked by marriage in an affirmation of existing hierarchies. "An equall yoke-fellow would be taken, of due proportion in state, birth, age, education, and the like, not much under, not much ouer, but fit and correspondent. . . The rich and noble will likely despise, or set light by the poorer and meaner: so will the younger doe the aged," observes Whately, suggesting potential conflicts that do in fact become crucial in Jacobean tragedy. ${ }^{81}$ When a marriage is socially unequal, however, it is always the husband's identity that determines the social status of the couple. If a man "of meane place be maried to a woman of eminent place," she must nevertheless acknowledge him as her superior: "It booteth nothing what either of them were before mariage . . for in giuing her selfe to be his wife, and taking him to be her husband, she aduanceth him aboue her selfe, and subiecteth her selfe unto him." 82 This merging and transforming of a woman's identity into her husband's finds its correlative in the legal status of Renaissance wives, who lost all property, rights, and power upon marrying. As Lawrence Stone summarily reminds us, "By marriage, the husband and wife became one person in law-and that person was the husband." 83

79. See, e.g., Perkins, p. 680; Calvin, p. I24; Gouge, pp. 217-19, 356, 425; and Whately, pp. 25-26, 73 .

80. Gouge, p. 219. Also see Keith Thomas, "The Double Standard," Journal of the History of Ideas, 20 (1959), I95-2I6.

8I. Whately, p. 73 .

82. Gouge, p. 272.

83. Stone, Family, Sex and Marriage, p. I95. Also see Barbara J. Todd, "The Remarrying Widow: A Stereotype Reconsidered," in Women in English Society, 1500-1800, ed. Mary Prior (London: Methuen, 1985), p. 55; and T. 


\section{The Expense of Spirit}

This comment suggests that the surrender of female identity demanded by patriarchal absolutism, which denied wives any status as individual actors, also denied them the status and power of subjects, or protagonists in the drama. Such a syndrome does in fact help to account for one notable development in English Renaissance drama, namely, the relative absence of mothers as protagonists. ${ }^{84}$ Yet as Stone himself shows, the legal construction and cultural ideology of marriage in the Renaissance, including the status of wives, was far from being definite and clear. Nowhere do these inconsistencies manifest themselves more openly than in the Puritan doctrine of wifely subordination and obedience.

Like the analogy connecting family, church, and state, the requirement that wives be obedient commands the absolute consensus of these domestic idealists. "By nature woman was made man's subject," Dod and Cleaver state baldly. ${ }^{85}$ Wives who fail to obey their husbands, pronounces Gouge in a stricture reiterated throughout the tracts, "thwart Gods ordinance, peruert the order of nature, deface the image of Christ, ouerthrow the ground of all dutie, hinder the good of the family, become an ill patterne to children and seruants, lay themselues open to Satan, and incurre many other mischiefes which cannot but follow vpon the violating of this maine duty of Obedience." 86 To obey does, henceforth, seem best. Yet, while fervently proclaiming and defining the subjection of women, the Puritans provide the necessary material for its subversion. After lionizing obedience, for example ("Let wiues be subject to their husbands in euerie thing"), Gouge urges women never to obey husbands who want them to do what "is forbidden by God." 87 In a similar vein, after demanding obedience and subjection (rising against husbands is the equivalent of rising against God), writers including Gouge, Dod and Cleaver, and Hieron urge women not only to disobey, but actively to seek to correct

E., The Lawes Resolutions of Womens Rights; or, The Lawes Provision for Woemen (London, I632), p. I I9, according to which the husband and wife "are but one person in Law, and the Feme taketh nothing but by agreement of the husband." Also see pp. I 29-30.

84. See Belsey, pp. I $55-60$.

85 . Dod and Cleaver (I 598), p. I 49.

86. Gouge, p. 287, italics his.

87. Gouge, pp. 295 (italics his), 328. 


\section{Heroics of Marriage in Renaissance Tragedy}

erring husbands. ${ }^{88}$ Furthermore, they define wives' subjection as merely temporal, temporary. "Her place is indeed a place of inferiority and subiection, yet the neerest to equality that may be," Gouge sums up, unhelpfully. ${ }^{89}$

Absolute spiritual and social equality between the sexes, coexisting with the equally absolute subjection of women that is decreed and then subverted-the logical inconsistencies that now appear so glaring, particularly given their consequences, seem never to have occurred to the Puritans. These contradictions and paradoxes permeate not only the conceptualization of women, but all matters concerning love, marriage, and sexuality in Puritan discourse. The moral ambivalence of sexual desire, for example, is fully documented yet only dimly perceived by the preachers, who in the same tracts treat eros variously as a solemn duty and a dangerous trap, the God-given, potentially joyful foundation of society and a necessary evil to be shunned except in procreation. ${ }^{90}$ Individual choice of a spouse and the of ten contradictory need for parental consent in marriage present a final example of the issues that are treated with distinct double-mindedness, in which reverence for hierarchy and obedience to authority clash with a growing middleclass distaste for property-based marriage and an as yet incompletely formulated notion of individual autonomy. ${ }^{91}$ Whately's declaration that a couple need not obey their parents- "in not suffering them to marrie in the Lord, but offering to force them marrie against the will of God . . . for no man can passe away anothers right, without his liking"-followed immediately by his equally adamant assertion that a couple marrying without parental consent lives in sin until "they haue procured an after-consent, to

88. Gouge, pp. 295, 328; Dod and Cleaver (I630), sig. o6r; Hieron, p. 4I I. 89. Gouge, p. 356, italics his.

90. On the equation of married love (sometimes eros is specifically meant) with happiness, see, e.g., Dod and Cleaver (1630), sig. K3; Gouge, pp. 225, 227, 4I5; Wing, pp. 85, 98, I00; and Smith, pp. I-40. For the (often ambivalent) association of sexual love with sin, see Gouge, p. 223; Dod and Cleaver (I 598), p. 98; and Whately, pp. 25-26, 36, 4I, 44, 66. Cf. Perkins, e.g., p. 67I; he disavows these associations.

91. See, e.g., Hieron, who speaks strongly (p. 405) against "the buying \& selling of children among parents," the "forced marriages, which mostly have the same issue of extreme loathing," and the unequal yoking "of an ox and an ass together." 


\section{The Expense of Spirit}

ratifie that, which ought not to haue been done before the consent" is typical. ${ }^{92}$

Belsey has stated that "marriage becomes in the sixteenth and seventeenth centuries the site of a paradoxical struggle to create a private realm and to take control of it in the interests of the public good." ${ }^{93}$ Indeed, it could be argued that the eager urgency of the Puritan analogies among family, church, and state, the very insistence on these relationships and the equal importance of the terms that constitute them, itself articulates a conflict between public and private realms and a profound anxiety about the need to draw them together. Similarly, the equation of marriage with love and happiness and the glimmering awareness of individual psychology and particular personality that some writers display indicate a dawning conception of privacy-that is, of autonomy or interiority-that involves a problematic notion of an individual self separate from the self manifested in society at large. That the $\mathrm{Pu}-$ ritans should glimpse these ideas to the point of admitting them into their domestic discourse and then fail to develop their logic has seemed to some scholars to be evasive and self-interested (i.e., an indication that the Puritans were seeking to establish their own spiritual authority and to profit from the publication of their sermons) and to others to thrust the Puritan idealization of marriage into incoherence. ${ }^{94}$ I do not believe that the Puritans, busily seeking to separate the present from the past and participating in the

92. Whately, pp. 33-34. Cf. T.E., Lawes Resolutions, p. 53, italics mine: "It is now received a generall opinion that the good will of parents is required, in regard of honestie, not of necessitie, according to the Canons which exact necessarily, none other consent but only of the parties themselves, whose Conjunction is in hand, without which the conclusion of parents is of none effect." T.E.'s separation of the moral and legal burdens constituting parental consent points to the moral ambiguity encompassing the whole issue. See also Goody, who argues (pp. 24-25) that the emphasis on consent in marriage "was not limited to countries of a particular demographic structure or historical destiny; it was a characteristic of the Christian Church as a whole, in principle from earliest times, and was in no way peculiar to the English. Indeed, the English Protestants reestablished the requirement of parental agreement in the sixteenth century although it was absent in Catholic doctrine, even though laymen often insisted on their veto."

93. Belsey, p. I 30.

94. See, e.g., Belsey, p. I 55; and Davies. 


\section{Heroics of Marriage in Renaissance Tragedy}

abstract and visionary formation of an ideology, were aware of the contradictions they were articulating. The value of their discourse does not lie in its self-consciousness or its prescience. ${ }^{95}$ Rather, because of its historical position, Puritan marriage ideology in the Renaissance provides a remarkable index of the ways in which modern sexual values were being created, terms were being constructed, and conflicts were taking shape. The apprehension and exploitation of ideological inconsistencies became the task not of sermons, but of the drama, in which a greater attachment to the concrete, an obligation to action, and a dependence on conflict brought paradox into the light of representation, giving visibility and significance to contradiction and seeking to resolve it through the operations of form.

In Othello the two predominant modes of English Renaissance sexual discourse meet and clash tragically. As we will see, the two sensibilities and styles overlap as well as conflict throughout the play. But in the complex exploration of sexuality that Othello comprises, the dualizing mentality that simultaneously exalts and degrades women and eros also is clearly distinguished from the heroics of marriage, which comes painfully into being, defined and comprehended as a failed achievement. It is not simply the competition between distinctive modes of sexual apprehension that issues in violence, however; the heroics of marriage also collapses from within, dissolving inevitably from its own unresolved contradictions.

We can begin by focusing on Act I, Scene 3, of the play, in which Desdemona and Othello seek to justify their marriage be-

95. For this reason the debate on whether or not Puritan marriage sermons and tracts are "feminist" is largely irrelevant. See, e.g., Juliet Dusinberre, Shakespeare and the Nature of Women (London: Macmillan, I975); and Linda T. Fitz, "What Says the Married Woman: Marriage Theory and Feminism in the English Renaissance," Mosaic, I 3 (Winter I980), I-22. The liveliest and most thorough summation/entry in this debate is Linda [Fitz] Woodbridge, Women and the English Renaissance: Literature and the Nature of Womankind, 1540-1620 (Urbana: University of Illinois Press, 1984). 


\section{The Expense of Spirit}

fore the Venetian Senate in response to Brabantio's outraged accusations of abduction and witchcraft. The materials that constitute the drama of this scene involve those in power demanding in a public forum to hear a detailed account of the intimate relationship of a newly married couple, much as King James demanded a narration of his daughter's wedding night. The two salient modes of sexual discourse, which are fully articulated and distinguished in the Senate scene, consequently take dramatic form as competing views of the relationship between private and public life.

As is noted often in commentaries on the play, Othello, a stranger and alien, founds his identity and assesses his own value in terms of his relationship to the Venetian state that has granted him membership in the community because of his exceptional abilities as a military leader. ${ }^{96}$ His self-confidence that his marriage will be politically sanctioned despite the honored insider Brabantio's objections is based on his sense of worthiness as a public servant ("Let him do his spite; / My services, which I have done the signiory, / Shall out-tongue his complaints" [1.2.17-19]). ${ }^{97}$ Similarly, he mourns his eventual loss of Desdemona as a surrender of professional status ("Farewell, Othello's occupation's gone!" [ $\left.\begin{array}{lll}3.3 & 363\end{array}\right]$ ); in attempting to recover his identity after discovering his fatal misapprehensions, he looks to his deeds of public service ("I have done the state some service, and they know't" [5.2.340]); finally, he construes his suicide as an act of justice against an enemy of Venice and, characterizing himself as "a malignant and a turban'd Turk" (5.2.354), assumes the dual role of criminal-outsider and state executioner in taking his own life. Othello's relationship to the state, forged through public service, is also personal and intimate, in that it permeates every aspect of his life and identity.

How can a man formed by and so devoted to public life integrate marriage as a source of primary meaning and value into his selfconception and experience? Othello, of course, is the hero of action par excellence. Like Tamburlaine's, his heroism combines superb

96. Cf. Helen Gardner, The Noble Moor (London: Oxford University Press, 1955), p. 192.

97. All quotations from Othello, identified in the text by act, scene, and line numbers, are from the Arden edition, ed. M. R. Ridley (London: Methuen, 1958). 


\section{Heroics of Marriage in Renaissance Tragedy}

military prowess with rhetorical magnificence and the status of an outsider whose merits and services "shall out-tongue . . . complaints" (I.2. I9). Again like Tamburlaine, Othello makes clear that he views private life not only as separate from public action, but also as subordinate to, and even potentially subversive of, public service. These beliefs are hinted at very early in the play, when Othello makes clear to Iago that he perceives marriage as opposed to freedom and the heroic style: "But that I love the gentle Desdemona, / I would not my unhoused free condition / Put into circumscription and confine / For the sea's worth" (I.2.25-28). It is the exception of love, then, that provokes Othello to marry; yet in persuading the Senate to allow Desdemona to accompany him to Cyprus, he elaborates a contempt for both eros and domesticity, characterizing each as trivial and idle:

And heaven defend your good souls that you think I will your serious and great business scant, For she is with me; . . . no, when lightwing'd toys And feather'd Cupid, foils with wanton dullness My speculative and active instruments That my disports corrupt and taint my business, Let housewives make a skillet of my helm.

$$
\text { [1.3.266-72] }
$$

In short, Othello feels that he must, in Bacon's terms, make love "keepe Quarter" by severing it "wholly, from . . . serious Affaires and Actions of life." Just as in Tamburlaine, then, the heroism of action accompanies a view of the private life as subordinate and subversive, and it is consequently associated with the necessary repression of sexuality. Othello makes this association clear when he characterizes his desire for his wife's company as follows:

$$
\text { ... I therefore beg it not }
$$

To please the palate of my appetite,

Nor to comply with heat, the young affects

In my defunct, and proper satisfaction,

But to be free and bounteous of her mind.

$$
\text { [I.3.26I-65] }
$$

Though the precise meaning of these extraordinary lines is contro- 


\section{The Expense of Spirit}

versial, 98 their purport is clear: sexual desire is degrading and potentially dangerous; marriage should involve a dignified separation between public and private life, in which the latter is clearly subordinate to the former. Like Tamburlaine, then, Othello confidently asserts his ability to subdue eros to public service. From the point of view of the heroism of action, his tragedy emerges from unsuccessful repression: desire proves more central to him, marriage more necessary, than such heroism will allow. ${ }^{99}$

Scholars have examined in depth, both in psychoanalytic and in sociocultural terms, the complex ways in which Othello associates sexual desire with fear, hatred, evil, sin, and finally death. Exploring Freud's theoretical formulations of "the ultimate incapacity of erotic instincts to be fully satisfied or harmonized," Arthur Kirsch views Othello's sexual tragedy as emerging from a striving after unconditional love that, rooted in the primary narcissism of a child's original attachment to its mother, is ultimately doomed to unfulfillment. Arguing that "the awesome energy of Othello's jealousy, its primitive and superstitious vindictiveness, is a function of the same primal forces that animated his earlier exaltation and love," Kirsch concludes that "Othello's jealous anguish suggests the tragic vulnerability of a love so absolutely rooted in, and dependent upon, the exaltation of symbiotic union." Citing Freud's analysis of "the dissociation of affection and sensuality . . . [that] are rarely completely fused in civilized man," Kirsch aptly describes the mentality that either degrades or idealizes women and desire as "the polarization of erotic love." 100 That the two instincts

98. See Arden edition, pp. 36-37.

99. See Richard S. Ide, Possessed with Greatness: The Heroic Tragedies of Chapman and Shakespeare (Chapel Hill: University of North Carolina Press, I980), esp. pp. 50-74. Ide deals with the ways in which Othello's attachment to the military/heroic ethic dooms him to domestic tragedy. Cf. Matthew N. Proser, The Heroic Image in Five Shakespearean Tragedies (Princeton, N.J.: Princeton University Press, I965), p. I Io; Proser makes a similar point. Both critics, however, regard this as a moral failing of Othello's, a judgement that does not correspond to my purpose and that seems beside the point when considering significance in tragedy.

I00. Arthur Kirsch, Shakespeare and the Experience of Love (Cambridge: Cambridge University Press, 1981), pp. 33, 37, 39. Also see Peter Erickson, Patriarchal Structures in Shakespeare's Drama (Berkeley: University of California Press, 1984), pp. 80-I03; Marianne Novy, Love's Argument: Gender Relations 


\section{Heroics of Marriage in Renaissance Tragedy}

inevitably coexist as a dichotomy in the play can be perceived in an exchange about Desdemona that takes place between Cassio and Iago in Act 2, Scene 3, where it becomes ominously clear how readily Cassio's idiom of sentimental exaltation can be translated into Iago's idiom of misogynistic contempt:

Iago. He [i.e., Othello] hath not yet made wanton the night with her; and she is sport for Jove.

Cas. She is a most exquisite lady.

Iago. And I'll warrant her full of game.

Cas. Indeed she is a most fresh and delicate creature.

Iago. What an eye she has! methinks it sounds a parley of provocation.

Cas. An inviting eye, and yet methinks right modest.

Iago. And when she speaks, 'tis an alarm to love.

Cas. It is indeed perfection.

Iago. Well, happiness to their sheets!

$$
[2.3 .15-25]^{101}
$$

Relating Othello to Protestant sexual discourse, Stephen Greenblatt adds to Kirsch's insights by emphasizing the negative view of desire embedded in Christian orthodoxy. The conjunction of sexual pleasure with sin and death, an association that persists-when pleasure is pursued immoderately-even within marriage, constitutes a tradition, Greenblatt argues, that leaves Othello vulnerable to Iago's unbearable equation of erotic love with inevitable adultery. Analyzing the blissful reunion between Othello and

in Shakespeare (Chapel Hill: University of North Carolina Press, 1985), pp. I 25-49; Sprengnether p. 93; Gohlke, pp. I70-87; Richard Wheeler, "Since First We Were Dissevered: Trust and Autonomy in Shakespearean Tragedy and Romance," in Schwartz and Kahn, pp. I 50-69; Irene G. Dash, Wooing, Wedding, and Power: Women in Shakespeare's Plays (New York: Columbia University Press, I98I), pp. I03-30; and Carol Thomas Neely, Broken Nuptials in Shakespeare's Plays (New Haven, Conn.: Yale University Press, 1985), pp. I05-35.

IOI. Cf. Kirsch, Shakespeare and the Experience of Love, p. 36: "Cassio idolizes Desdemona and at the same time is capable of a sexual relationship only with a whore of whom he is essentially contemptuous." See also Neely, whose view of Bianca (pp. I22, I34) is considerably more sympathetic than that of Kirsch or of Cassio. 


\section{The Expense of Spirit}

Desdemona on Cyprus after the storm (2.I), Greenblatt explores the ways in which Othello's expressions of ecstatic love, intimately intertwined with thoughts of death (i.e., "If it were now to die, / 'Twere now to be most happy" [2.I.I89-90]), convey not only gratified desire but "the longing for a final release from desire, from the dangerous violence, the sense of extremes, the laborious climbing and falling out of control that is experienced in the tempest." 102 We have seen a similarly pressing need to render inert the tumultuous, anarchic motions of desire in Tamburlaine, another play in which the simultaneous exaltation and degradation of women and eros combines with the heroism of action to constitute a hierarchical relationship between a privileged public and a subordinate private life.

But the conjoined repression and idealization of eros, with its accompanying consignment of women and marriage to the periphery of serious endeavor, is by no means the only possible relationship between public and private life that the play represents; nor does this polarizing sensibility fully account for Othello's experience. Indeed, in the Senate scene, the moment when competing conceptions of marriage and sexuality are articulated, Othello's stated view that the two domains must remain rigorously separate is echoed, oddly, only by Brabantio. "Neither my place, nor aught I heard of business, / Hath rais'd me from my bed, nor doth the general care / Take any hold of me, for my particular grief / Is of so flood-gate and o'erbearing nature / That it engluts and swallows other sorrows, / And it is still itself," Brabantio insists hysterically, distinguishing personal from political concerns as he bursts into the Senate, interrupting a war council in an endeavor to recover his daughter (I.3.53-58). Attempting to reestablish self-control throughout his subsequent speeches, Brabantio persists in making this distinction: "Please it your grace, on to the state affairs; / I had rather to adopt a child than get it; . . Beseech you now, to the affairs of state" (I.3.190-9I, 220). On the issue of segregating public and private life, then, Brabantio and Othello are in agree-

I02. Greenblatt, p. 243, his italics. See also Denis de Rougemont, Love in the Western World, trans. Montgomery Belgion (New York: Harcourt, Brace, I940); and Sigmund Freud, Beyond the Pleasure Principle, trans. James Strachey (New York: Norton, I96I). 


\section{Heroics of Marriage in Renaissance Tragedy}

ment instead of conflict in the Senate scene. This tacit emotional alliance between them, rather than the nonexistent truth-value of the assertion, lends Brabantio's warning to Othello an eerie clairvoyance: "Look to her, Moor, have a quick eye to see: / She has deceived her father, may do thee" (I.3.292-93).

Desdemona, not Brabantio, unwittingly articulates a conception of sexuality and its relation to public life that is antagonistic to Othello's. Openly and proudly acknowledging her love for her husband, Desdemona characterizes herself as a soldier-spouse, adopting the vocabulary of the epic quest:

That I did love the Moor, to live with him, My downright violence, and scorn of fortunes, May trumpet to the world: my heart's subdued Even to the utmost pleasure of my lord: I saw Othello's visage in his mind, And to his honours, and his valiant parts Did I my soul and fortunes consecrate: So that, dear lords, if I be left behind, A moth of peace, and he go to the war, The rites for which I love him are bereft me.

$$
[\text { I.3.248-57 }]^{103}
$$

In contrast to Othello's emphatic severance of body and mind (I.3.26I-65), Desdemona's definition of marriage conjoins physical and mental life. As has been suggested, the radical distinction between her experience of desire and Othello's is clarified during their reunion on Cyprus. Where Othello seeks release and inertia ("It stops me here, it is too much of joy" [2. I. 197]), Desdemona anticipates growth and fruition ("The heavens forbid / But that our loves and comforts should increase, / Even as our days do grow" [2. I. I93-95]). ${ }^{104}$ Furthermore, by using a quasi-military idiom to insist that separation between spouses makes non-sense of marriage, and by associating herself with the Turkish wars, she also

I03. Ridley's choice of the Quarto's $\left(Q_{1}\right)$ "utmost pleasure," rather than the Folio's "very quality," in line I 5 I of this passage in the Arden edition, which I accept, obviously serves to highlight Desdemona's eroticism.

I04. Cf. Greenblatt, pp. 240-44; and Kirsch, Shakespeare and the Experience of Love, pp. 25-27. 


\section{The Expense of Spirit}

emphatically draws together public and private domains. In the paradoxically active submission that Desdemona describes herself as undertaking in her marriage, expressed in military terms, we can recognize the dynamic obedience and devotion idealized in the Puritan tracts. In short, Desdemona presents herself to the Senate as a hero of marriage.

In defining marriage as a heroic endeavor, Desdemona, like the Puritans, analogizes public and private life, drawing them together and granting them equal distinction, rather than establishing a hierarchy in which the latter is clearly subordinated to the former in dignity, interest, and importance. And her visionary construction of marriage is borne out by the structure of the play. The action of the Senate scene, in which the Senators dispatch their decisions about the Turkish enemy with quick, acute rationality, changes rapidly to focus on Othello's private life, revealing the general's marriage not as a peripheral matter, but as an event of the most decided political significance. ${ }^{105}$ That Othello's intimate being is directly connected to affairs of state is, again, an assumption basic to his identity, revealing his insistence on the separation between love and duty as an unrecognized contradiction that becomes a fatal delusion. Similarly, in the second act, the Turkish enemy is again introduced and then quickly dismissed as the significant component at issue; instead the focus of central dramatic meaning and conflict turns out to be love and marriage. In recalling the associations of the tempest that perilously escorts Desdemona and Othello to Cyprus with the unpredictability and dangers of eros, we can also recall the Puritan conception of marriage as a heroic voyage on a dangerous sea: "such a continual storm and tempest to those that launch not forth in a prosperous gale . . it is such a sea, wherein so many shipwreck for want of better knowledge and advice upon a rock."106

Viewed from the perspective of transforming conceptions of heroic experience, the first and second acts of Othello can be seen to represent the process of the heroism of action giving way to the heroism of endurance associated with marriage. The conflict of

I05. Cf. Alvin B. Kernan, "Othello: An Introduction," in his Modern Shakespearean Criticism, pp. 353-54; and Neely, p. I09.

I06. Niccholes, pp. I60-6I. 


\section{Heroics of Marriage in Renaissance Tragedy}

allegiances between eros and action, so precisely defined and resolved by Tamburlaine, who simply relegates private life to a peripheral and subordinate position, is in Othello obsolete. Differentiating between love and duty and subduing beauty to heroism are no longer the necessary tasks. Indeed, they are deluded efforts, for the play quickly makes clear that the hero's major task has become the conduct of marriage itself: "for marriage is an adventure, for whosoever marries, adventures; he adventures his peace, his freedom, his liberty, his body; yea, and sometimes his soul too." 107

Othello's sexual tragedy therefore emerges not as insufficient repression, the criterion of the heroism of action, but as a misconstruction of his heroic quest. The ironies of his delusions are multiple, because the play makes clear that Othello is in many ways well equipped to undertake the heroics of marriage. As Greenblatt points out, he responds to love and marriage precisely as an adventure, "a supreme form of romantic narrative, a tale of risk and violence issuing forth at last in a happy and final tranquillity." 108 Indeed, despite his own disclaimers, Othello's embrace of marriage as a perilous quest duplicates, rather than contrasts with, his attitude toward public service. For example, in stark contrast to Tamburlaine's perpetually imperious vocabulary ("for will and shall best fitteth Tamburlaine" [I.3.3.4I]), which the revolutionary shepherd uses to slaughter existing monarchs and to create a new society under his own rule, Othello's rhetoric is that of a humble suitor seeking recognition and acceptance by the established state ("Most potent, grave, and reverend signiors / My very noble and approv'd good masters"; "Rude am I in my speech"; "I do beseech you"; "Your voices, Lords: beseech you"; "With all my heart"; "Please your grace"; "We must obey the time" [1.3.76-77, 8I, I I4, 260, 278, 283, 300]-these are his typical modes of address). ${ }^{109}$ The posture of dignified humility that Othello assumes toward the state resembles the dynamic obedience described in the Puritan tracts as an essential component for protagonists in the heroics of marriage. And the contrast between

I07. Niccholes, p. 162.

I08. Greenblatt, p. 243.

I09. Cf. Gardner, pp. I93-94. 


\section{The Expense of Spirit}

Othello and Tamburlaine is replicated in their methods of courtship. Where Tamburlaine rapes Zenocrate, establishing his dominion by force, Othello entertains and woos Desdemona in response to her desire, observing her closely and allowing her to take the lead (I.3.144-70). Interestingly, Othello also characterizes his heroism as much in terms of suffering as of action, or more precisely, in terms of the endurance that constitutes a dynamic combination of the two: "I spake of most disastrous chances, / Of moving accidents by flood and field; / Of hair-breadth scapes i'th'imminent deadly breach; / Of being taken by the insolent foe;/ and sold to slavery, and my redemption thence" (I.3.I34-38). ${ }^{110}$ His original attitude toward Desdemona conveys the same loving submission to a power that will enhance and complete his own; along with direct acknowledgment of the intimate connection between his love for her and his military prowess: "She lov'd me for the dangers I had pass'd, / And I lov'd her that she did pity them" (I. 3. I67-68). ${ }^{111}$

Freedom for Othello therefore would seem to lie in a commitment to the heroics of marriage, yet he is unable adequately to make the leap from the hierarchies of the heroism of action to the analogies of the heroism of marriage. Just as he unwittingly articulates a profound ambivalence toward the ecstasy and dangers of desire in his reunion with Desdemona on Cyprus, Othello in the Senate scene emphasizes the associations between eros and action that are crucial to him even as he denies them, vigorously insisting on the absolute separation between public and private life. In contrast, subordinating the private life without ambivalence, Tamburlaine is able to reconcile its established marginality with the polarization of erotic love that removes women and eros from the realm of significant action by exalting or degrading them: for Tamburlaine the heroics of marriage is not a possibility. But Othello, for whom marriage has become central, rather than peripheral, remains torn between the two perspectives, unable wholly to admit the claims of either. Like Niccholes, who views marriage as "this one and absolutely greatest action of a man's whole life," asserting that "there is in marriage an inevitable

I Io. Cf. Hunter, "The Heroism of Hamlet," p. 108.

I I I. Erickson, pp. 89-92. 


\section{Heroics of Marriage in Renaissance Tragedy}

destiny," 112 Othello acknowledges the critical importance of his marriage to his identity and his fate, defining it as "there, where I have garner'd up my heart, / Where either I must live, or bear no life, / The fountain, from the which my current runs / Or else dries up" (4.2.58-6I). Yet, along with being unable to absorb the centrality of his marriage into his conception of himself as a public servant, Othello is unable to master the one quality that is essential to the successful undertaking of the heroics of marriage, namely, patience. The possibility of Othello's submitting to his suffering with patient endurance is transformed insidiously by Iago into the humiliating picture of the oblivious cuckold that was the source of profound anxiety, reflected by endless, derisive jokes, in Jacobean society. ${ }^{113}$ Significantly, when explaining why patience is impossible for him, Othello makes a distinct separation between the demands of public and private identity:

Had it pleas'd heaven

To try me with affliction, had he rain'd

All kinds of sores and shames on my bare head,

Steep'd me in poverty, to the very lips,

Given to captivity me and my hopes,

I should have found in some part of my soul

A drop of patience; . . .

But there, where I have garner'd up my heart. . . .

[4.2.47-54, 58, italics mine]

I 12. Niccholes, pp. I64, I73.

II3. See 4. I.6I-89:

Iago. Would you would bear your fortunes like a man!

Oth. A horned man's a monster, and a beast.

Iago. There's many a beast then in a populous city,

And many a civil monster . . .

Think every bearded fellow that's but yok'd

May draw with you ... .

Confine yourself but in a patient list . . . ... marry, patience,

Or I shall say you are all in all in spleen, And nothing of a man.

See also Keith Thomas, "The Place of Laughter in Tudor and Stuart England," Times Literary Supplement, 2 I January I977, pp. 77-8I. 


\section{The Expense of Spirit}

In this context, Othello's tragic conflicts are strikingly defined in the magnificent speech that articulates his belief in Desdemona's infidelity: "O now for ever / Farewell the tranquil mind, farewell content: / Farewell the plumed troop, and the big wars, / That makes ambition virtue: . . Farewell, Othello's occupation's gone!" (3.3.353-64). In this moving elegy to the heroism of action, three points are salient. First, Othello acknowledges the indissoluble link between his public and his personal life by describing the loss of the one as the loss of the other. Yet he has leaped over the construction of a comparison between the two domains. By absorbing Desdemona entirely into the terms of his professional identity he denies the analogous connection between the two that prompted him to make the speech in the first place. Consequently, though he acknowledges the centrality of his marriage, he apprehends desire as a loss, a sign of human inadequacy and subversion of identity. Othello's erotic ambivalence, together with his inability to accept the emotional consequences of the connections he recognizes between public and private life, combine to disqualify him as a protagonist in the heroics of marriage. Unable to embrace the humility and patience that marriage requires, he construes his murder of Desdemona as an execution of justice and revenge undertaken (dispassionately) as a public service, thus misapplying to his marriage the criteria of the heroism of action that he himself has dimly perceived as obsolete (eg., 5.2.6 and 5.2.65-66): "Even so my bloody thoughts with violent pace / Shall ne'er look back, ne'er ebb to humble love, / Till that a capable and wide revenge / Swallow them up" (3.3.464-67).

The thrust of this analysis has implied that the heroics of marriage is the liberating, progressive discourse in Othello. A commitment to its assumption of the prestige and centrality of the private life and to its terms of patient endurance might indeed have averted tragedy. Yet it is not simply that such a commitment proves impossible for Othello and would require either a sermon or another play; more important, the heroics of marriage itself constitutes a tragic discourse. As noted above, the requirements of the heroics of marriage resemble those of the Renaissance idealization of women; thus, although this discourse is concerned with both sexes, its materials have a particular relevance to women, allowing them a mode in which they can define themselves and be perceived 


\section{Heroics of Marriage in Renaissance Tragedy}

as heroes. ${ }^{114}$ Accordingly in Othello the articulation and breakdown of the idealization of marriage are dramatized in the career of Desdemona.

As recent studies of the fashioning of identity in the Renaissance make clear, verbal mastery becomes one of the primary characteristics of the hero, essential for the maintenance of power as well as the achievement of social mobility. ${ }^{115}$ Much of the action in Othello depends upon the characters' submission to and creation of narrative. Othello's account to the Senate of his courtship of Desdemona becomes a metanarrative, a successful act of persuasion in which is embedded the story of another successful act of persuasion. He has won his wife by telling his tale: "She lov'd me for the dangers I had pass'd / And I lov'd her that she did pity them" (I.3.I63-68). "I think this tale would win my daughter too," says the Duke, as a way of sanctioning the marriage when Othello has finished his account (I.3.I7I). Confirming the centrality of narrative discourse to their courtship, Desdemona adds, "I saw Othello's visage in his mind" (I.3.252), implicitly equating her erotic responsiveness to her husband, which she explicitly defines, with the act of listening to his life history. The love and marriage between Desdemona and Othello are therefore construed as the triumphant ability of language to constitute reality.

Terry Eagleton has argued that "when language is cut loose from reality, signifiers split from signifieds, the result is a radical fissure between consciousness and material life."116 As is well known, such a fissure is necessary for Othello and Desdemona, who must absorb, or overcome, the material obstacles of Othello's age, his blackness, and his foreignness, which to varying degrees are perceived as impediments by every character in the play. ${ }^{117}$ Thus at the start of the play Desdemona and Othello have experienced the power and independence of language as liberating and enabling; they equate language with desire and perceive their ability to form and manipulate both as endlessly creative. But as Eagleton points out, the effects of linguistic autonomy, "a kind of

I I4. Cf. Lamb; and Rose, "Gender, Genre, and History," pp. 259-67.

I I5. See n. 36, above.

I I6. Terry Eagleton, William Shakespeare (Oxford: Basil Blackwell, I986), p. 7 .

I 17. Cf. Kirsch, Shakespeare and the Experience of Love. 


\section{The Expense of Spirit}

discursive imperialism, in which words determine reality rather than the other way round," can be dangerously chaotic as well. When signs are detached from the material world, reality becomes flexible and manipulable on the one hand; but on the other, a vacuum can result in which "signs are now purely ... dead letters emptied of all constraining content and so free to couple . . . in an orgy of inbreeding. . . . A sign can be roughly defined as anything which can be used for the purpose of lying." 118 The arch-liar of the play, Iago, of course proves time and again the power of words to triumph over visual and material reality; in this context Othello's vulnerability to Iago's fictions can be seen as paradoxically related to his own loving sensitivity to the claims of autonomous discourse. Eagleton's insight clarifies the ways in which the creative potential of language in Othello is inextricably intertwined with its destructive power. "All that's spoke is marr'd," comments Gratiano at the conclusion of the play (5.2.358), in an effort to characterize the defeated potential constituting the tragic situation.

Desdemona both creates and is enveloped by the tragic paradoxes of language. The untenable position that she occupies in the action can best be described by noting that she makes three remarkable attempts to save her marriage in the play, and that each attempt is a lie. In examining her three lies, we can see that each issues from the paradoxical, contradictory materials that compose the heroics of marriage.

Desdemona's first lie involves not telling her father about her marriage. Strictly speaking, this lie of omission precedes the action and is responsible for generating the preliminary conflicts in the play. Brabantio's superstitious horror at his daughter's secret elopement with an aging Moor clearly distinguishes him as the irrational contender in the Senate scene; no matter how ominously qualified, the lovers' happiness and confidence command greater sympathy than the racist torment of the shattered, deceived father. It immediately becomes clear that Brabantio's conception of his daughter as "a maiden never bold of spirit, / So still and quiet that her motion / Blush'd at her self" (I.3.94-96), couched in the traditional terms of the Renaissance idealization of women as silent,

I I 8. Eagleton, pp. 6-9. Cf. Mueller, who argues (p. 6) in another context that in Othello, "the destructiveness and destruction of grand language are the subject matter of the play." 


\section{Heroics of Marriage in Renaissance Tragedy}

chaste, and obedient, is based fragilely on the most oblivious paternal self-deception. In defending her marriage before the Senate, Desdemona not only manifests courage and determination, she defines herself as a full-fledged subject, who assumes the legitimacy and priority of her independent desires and actions: "I did love the Moor to live with him ... ; "My heart's subdued / Even to the utmost pleasure of my lord"; "I saw Othello's visage in his mind / And to his honours, and his valiant parts / Did I my soul and fortunes consecrate"; "The rites for which I love him are bereft me" (I.3.248-57, italics mine). It is important to stress that what commentators have seen as Othello's "male dream of female passivity" is by no means presented unequivocally in this scene. ${ }^{119}$ In contrast to Brabantio's admiration for his daughter's alleged silence and obedience, Othello responds with loving pleasure to Desdemona's self-assertion:

She gave me for my pains a world of sighs;

She swore i' faith 'twas strange, 'twas passing strange;

'Twas pitiful, 'twas wondrous pitiful;

She wish'd she had not heard it, yet she wish'd

That heaven had made her such a man: she thank'd me,

And bade me, if I had a friend that lov'd her,

I should but teach him how to tell my story,

And that would woo her. Upon this hint I spake.

$$
\text { [I.3. I 59-66] }
$$

Indeed, Othello's lingering attachment to his view of Desdemona as an active, separate person asserts itself in his last attempt against succumbing to jealousy:

'Tis not to make me jealous

To say my wife is fair, feeds well, loves company, Is free of speech, sings, plays, and dances well;

Where virtue is, these are more virtuous:

Nor from mine own weak merits will I draw

The smallest fear, or doubt of her revolt,

For she had eyes, and chose me.

[3.3. I $87-93]$

Scholars have demonstrated convincingly the ambivalence and I I9. See, e.g., Greenblatt, p. 239. 


\section{The Expense of Spirit}

narcissism of Othello's love for Desdemona, insights with which I fully agree. ${ }^{120}$ Here I wish to stress, however, that whatever illusions are involved in Desdemona and Othello's marriage, Desdemona, like Juliet, Rosalind, Portia, Viola, and Olivia, chooses freely to enter into them; at this point in the play she is not merely a victim and object of Othello's desires and fears, but a subject, with her own, distinctive set of actions and priorities. ${ }^{121} \mathrm{It}$ is true that the terms in which Desdemona describes her own conflict in the Senate scene, picturing herself as bound either to father or to husband, seem to undermine her assertions of independence and subjectivity:

My noble father,

I do perceive here a divided duty: . . .

My life and education both do learn me

How to respect you, you are lord of all my duty,

I am hitherto your daughter: but here's my husband:

And so much duty as my mother show'd

To you, preferring you before her father,

So much I challenge, that I may profess,

Due to the Moor my lord.

$$
\text { [1. 3. 180-89] }
$$

The unresolved paradoxes inherent in the ideals of female equality and wifely obedience do contribute to her destruction. Although the lines just quoted suggest the contradictions inherent in Desdemona's assumption of autonomy, however, these potentially disturbing issues are deflected at the beginning of the play.

Like Othello's construction of a conflict between love and duty,

I 20. See Greenblatt; and the references in n. Ioo above.

I 2 I. See Eagleton, who chastises (e.g., pp. 69-70) Othello's "wholly 'imaginary' relation to reality; his rotund, mouth-filling rhetoric signifies a delusory completeness of being, in which the whole world becomes a signified obediently reflecting back the imperious signifier of the self. Even Desdemona becomes his 'fair warrior,' as though he can grasp nothing which he has not first translated into his own military idiom." Desdemona does not simply accept such translations of her identity, however, but actively creates them herself; further, the military idiom, absorbed and transformed by domestic idealism, is part of the larger cultural vocabulary of the heroics of marriage. 


\section{Heroics of Marriage in Renaissance Tragedy}

Desdemona's description of a conflict of loyalties between husband and father turns out to be easily dealt with, obsolete. No one at this point in the play, including Brabantio, questions the well-established and accepted priority of wifely obedience or primary loyalty to a spouse. Brabantio's bitter grievance lies instead with Desdemona's failure to gain his consent for her marriage: it is this omission that constitutes her deception. Rather than finding, as he had assumed, that chaste modesty is the source of his daughter's opposition to marrying one of the "wealthy curled darlings of our nation" (I.2.68), he discovers that she has been "half the wooer," determined to love the man she wants to love and to choose a spouse for herself (1.3.176), a decision that she presents to her father as a fait accompli.

It is in the context of selecting her own mate that Desdemona inscribes herself in the heroics of marriage (I.3.248-59), and at this point it is useful to recall the paradoxical view of parental consent to marriage embedded in that discourse. Time and again the Protestant idealizers of marriage protest vehemently the common phenomenon of parents forcing children to marry against their will; inexplicably, they are equally resistant to the idea of children marrying without parental consent. "No man can passe away anothers right, without his liking," William Whately asserts in seeming defense of individual choice of a spouse; yet as we have seen, he immediately adds that a couple marrying without parental consent are living in sin until "they haue procured an after-consent, to ratifie that, which ought not to haue been done before the consent." ${ }^{122}$ It is precisely this ambivalence in which Desdemona is trapped. Clearly, her father's superstitious abhorrence would have caused him to withhold his consent; Brabantio himself admits that had he known his daughter's inclinations, he would have gone to any lengths, including forcing her to marry the despised Roderigo, in order to impede them (I.2.I76). Desdemona's marriage to Othello consequently requires elopement. Yet the fact that Brabantio remains permanently unreconciled to the match creates a lingering, negative resonance throughout the play that is never overcome: "If you have lost him, / Why, I have lost him too," Desdemona reminds Othello (4.2.47-48) ; and Gratiano's first re-

I22. Whately, p. 34 . 


\section{The Expense of Spirit}

action to Desdemona's murder is to remark, "Poor Desdemona, I am glad thy father's dead; / Thy match was mortal to him, and pure grief / Shore his old thread atwain" (5.2.205-7). Thus the play keeps subtly alive the associations between Desdemona's independent act of choosing her own spouse with death and sin. These associations explain her otherwise illogical deathbed response, "They are loves I bear to you," to Othello's warning, "Think on thy sins" (5.2.39-40). Thus Shakespeare dramatizes the contradictions inherent in individual choice and parental consent in the heroics of marriage by establishing Desdemona's match as courageous and triumphant, while giving it the discursive status of a lie.

The unresolved dilemmas implied and hinted at in Desdemona's first lie explode into tragedy in the circumstances surrounding the second and third. Once again Desdemona's predicament can be located in the contradictory terms in which female identity is constructed in the heroics of marriage. To reiterate, the Puritans both assert and deny female equality and subjectivity. They consider women equal to men in the sight of God and value them for their domestic capabilities, as well as their spiritual and physical companionship; they often grant women's rights and desires in marital sexual relations, usually referred to as "mutual benevolence," as much validity as those of men. When focusing on the issue of individual choice of a spouse, the Puritans frequently ignore gender or, like Niccholes and Wing, address males exclusively. Yet many argue for the woman's need to choose and consent, as well as the man's. Dod and Cleaver, for example, insist that a couple should spend as much time as possible together during courtship, observing each other: "It must be a mutual promise, that is, either party must make it to other, not the man only, nor the woman only, but both the man and the woman"; otherwise, "it is no true and perfect contract." 123 Even as they argue for female equality in sexual relations and (occasionally) independence in choosing a mate, however, the Puritans are constantly establishing the wellknown if ambiguous hierarchy of domestic power, recommending that women help and advise their husbands while insisting on

I23. Dod and Cleaver (I 598), pp. I08-9, I 22. 


\section{Heroics of Marriage in Renaissance Tragedy}

wif ely obedience, silence, and subjection: "Hee is her head, and shee his glorie."124

We can recall that in the Senate scene Desdemona defines herself precisely in terms of choice and desire: "I did love the Moor, to live with him" (I.3.248). Othello has responded to his wife's independence and self-conception during courtship with joyous pleasure, muted only by an ambivalence of which, at this point, he remains dimly aware. Yet it is precisely these qualities of self-assertion that combine with terrible irony to ruin Desdemona. As Kirsch and Greenblatt have demonstrated, her eroticism becomes for the deluded Othello the very source of his anguish, just as her autonomy in choosing him takes on the insidious characteristics of deception. Iago's fictions gradually coax Othello toward alienation, leading him to give credence to his hitherto unrecognized agreement with Brabantio:

Iago. She did deceive her father, marrying you; And when she seem'd to shake and fear your looks, She lov'd them most.

Oth. And so she did.

$$
\text { [3.3.210-I3] }
$$

In a similar vein, Desdemona's loyalty, liveliness, and self-assertion take a bitterly ironic and self-defeating form after her marriage, when she focuses on pleading for Cassio, her suspected partner in adultery. When, after succumbing to Iago's temptation, Othello begins to confront Desdemona with his suspicions, the heroics of marriage collapses into its irreconcilable contradictions, adding force to the unyielding claustrophobia of the play. This process reaches a climax at Desdemona's second lie, which involves her loss of the handkerchief that was Othello's first gift to her.

As noted, Desdemona's self-presentation in the Senate scene is couched in a quasi-military idiom, in which she identifies herself with Othello's profession of soldier, an association reiterated in descriptions of Desdemona by herself and others throughout the play. (e.g., 2.I.74; 2.I.75; and 3.4. I49). In this same speech she establishes her identity as a wife in terms of the dynamic, chosen

I24. Dod and Cleaver (I598), pp. I22-23. 


\section{The Expense of Spirit}

submission defined in Protestant sexual discourse: "I saw Othello's visage in his mind, / And to his honours, and his valiant parts / Did I my soul and fortunes consecrate" (I.3.252-54). Desdemona's conflation of her desire and devotion with Othello's profession therefore unites public and private life in the analogous association idealized in Protestant sexual discourse. Othello's account of their courtship further clarifies his wife's identification with his heroic exploits; indeed, it is the "strangeness" of these endeavors, their legendary quality, that have enchanted her, thus making her selfassertion and their marriage possible. (1.3.128-70). When Desdemona lies to Othello about losing the handkerchief he gave her, however, it is precisely her allegiance to the exotic quality of his narrative reminiscences, the power of the discourse that won her love, which recoils to overwhelm and terrify her. The moment of the second lie is worth quoting at length:

Oth. I have a salt and sullen rheum offends me, Lend me thy handkerchief.

Des. Here, my lord.

Oth. That which I gave you.

Des. I have it not about me.

Oth. Not?

Des. No, faith, my lord.

Oth. That's a fault: that handkerchief Did an Egyptian to my mother give, She was a charmer, and could almost read The thoughts of people; . . .

To lose, or give't away, were such perdition As nothing else could match.

Des. Is't possible?

Oth. 'Tis true, there's magic in the web of it; A sibyl, that had number'd in the world The sun to make two hundred compasses, In her prophetic fury sew'd the work; The worms were hallow'd that did breed the silk, And it was dyed in mummy, which the skillful Conserve of maidens' hearts.

Des. I' faith is't true?

Oth. Most veritable, therefore look to't well. 


\section{Heroics of Marriage in Renaissance Tragedy}

Des. Then would to God that I had never seen it!

Oth. Ha, wherefore?

Des. Why do you speak so startingly and rash?

Oth. Is't lost? is't gone? Speak, is it out o' the way?

Des. Heaven bless us!

Oth. Say you?

Des. It is not lost, but what an if it were?

Oth. Ha!

Des. I say it is not lost.

$$
[3 \cdot 4 \cdot 47-82]
$$

Interestingly, Desdemona next attempts to respond to Othello's exotic tale of the handkerchief much as she did during the legends of his courtship, with an act of self-assertion:

Oth. Fetch't, let me see it.

Des. Why, so I can sir, but I will not now, This is a trick, to put me from my suit, I pray let Cassio be receiv'd again.

Oth. Fetch me that handkerchief, my mind misgives.

Des. Come, come,

You'll never meet a more sufficient man.

Oth. The handkerchief!

$$
\text { [3.4.83-89] }
$$

Aside from the fateful irony of her choice of subject, Desdemona's attempt to distract Othello, which persists for several more lines after the passage just quoted, now appears to him as willfulness, wif ely disobedience. Endeavoring to declare her independence from Othello's discourse, she succeeds only in compounding the lie. Her identity as a subject, constituted by her active, chosen responsiveness to her husband's narrations, consequently begins to dissolve.

Initiated in the course of her second lie, this process of dissolution continues when Desdemona, overwhelmed by Othello's anguish, retreats from efforts to understand to fragile rationalizations of his behavior. Significantly, these rationalizations are expressed as an acknowledged division between public and private life, in 


\section{The Expense of Spirit}

which the latter is regarded as subordinate and inferior to the former:

Something sure of state,

Either from Venice, or some unhatch'd practice,

Made demonstrable here in Cyprus to him,

Hath puddled his clear spirit, and in such cases

Men's natures wrangle with inferior things,

Though great ones are the object.

$$
\text { [3.4. I 37-42] }
$$

In this speech, Desdemona reverses her conception of marriage as a heroic endeavor, uniting public and private domains and granting her status as a subject. As we have seen, this status is equivocal at best and is inscribed in a discourse that succumbs to its own contradictions. That wifely heroism is itself a contradiction becomes manifest in Desdemona's third lie. Attempting to protect Othello from being discovered as her murderer, Desdemona responds to Emilia's "O, who has done this deed?" with "Nobody, I myself, farewell" (5.2.124-25). Desdemona's final effort to identify with and absorb herself in her husband's actions (itself the definition of marriage in this play) becomes an act of self-assertion that is, simultaneously, an act of self-cancellation: "Myself" is the equivalent of "Nobody." Constituting the final dissolution of Desdemona's identity, the third lie is a dying voice. In this context Othello's outraged retort, "She's like a liar gone to burning hell, / 'Twas I that kill'd her" (5.2.I30-3I), could be read as a protest against his wife's destruction. But it is too late; the assertive and lively woman who "is fair, feeds well, loves company, / Is free of speech, sings, plays, and dances well" has disappeared, along with the troublesome contradictions of the heroics of marriage. Her chastity reestablished, Desdemona, like Zenocrate, is rendered inert, removed from the realm of significant action. Brabantio's fantasy of "a maiden ... So still and quiet, that her motion / Blush'd at herself" is consummated in the figure of the dead Desdemona "as monumental alabaster . . . one entire and perfect chrysolite," the "heavenly sight" with which Othello concludes (5.2.5; I46; 279). 


\section{Heroics of Marriage in Renaissance Tragedy}

The resolution of the action can be understood by examining the conjoined mechanisms of the play's complex treatment of language and sexuality. In her martyrdom Desdemona returns, as it were, from the dead and lies in a self-sacrificing attempt to shield Othello. Both directly before and af ter the murder he idealizes her chastity as "whole," "entire," "perfect," and "alabaster," using terms that suggest virginity and stasis. Thus he denies her liveliness and wifehood and reveals both his longing and the desire to be released from that longing. In the process initiated by Desdemona's third lie, then, husband and wife in a sense conspire to retrieve the realm of autonomous discourse in which, discounting social and material circumstances, they originally constructed their courtship and defined their marriage. Yet the power to create reality through language has increasingly become identified in the play with lying. Itself a lie, Desdemona's final self-abnegation initiates the resolution of the action and is essential to it, though it is inadequate to bring the conflict to completion. What is needed to finish that process is not autonomous discourse, but "a material limit before which the power of discourse is disarmed." 125 It is not Desdemona's martyrdom that convinces Othello of her fidelity, but Emilia's defiant self-assertion, rooted as it is in narrating the actual circumstances of Iago's deceptions. In a small exchange with Othello that takes place after she discovers the murdered Desdemona, Emilia distinguishes herself precisely in these terms:

Oth. Why, how should she be murder'd?

Emil. Alas, who knows?

Oth. You heard her say, herself, it was not I.

Emil. She said so, I must needs report a truth.

[5.2.I $28-3 \mathrm{I}]$

It is significant that Emilia's revelations are all couched within the contradictory discourse of the heroics of marriage. Discovering that she has unwittingly contributed to her mistress's murder by adhering to wifely silence and obedience (i.e., in confidentially stealing Desdemona's handkerchief at her husband's request), she

I25. Eagleton, p. Io. 


\section{The Expense of Spirit}

now realizes that her only recourse is to speak and disobey: "I am bound to speak," she replies to Iago's attempts to silence her, "I hold my peace sir, no, / I'll be in speaking, liberal as the air, / Let heaven, and men, and devils, let 'em all, / All, all cry shame against me, yet I'll speak" (5.2.185, 220-24). Here Emilia's declarations summon the paradoxical associations of speech throughout the play both with truth and with the incipient violation of established order; specifically, her linkage of her own courage and self-assertion with possible shame evokes the contradictions of the heroics of marriage. When we recall the Puritans' ambiguous injunction that a wife must obey her husband absolutely unless he commands what "is forbidden by God," we can perceive Emilia's predicament as an irreconcilable conflict between the private obligations of a wife (loyalty, silence, and obedience) and the public duties of a citizen (revelation of a murder): "Good gentlemen, let me have leave to speak. / 'Tis proper I obey him, but not now: / Perchance, Iago, I will ne'er go home" (5.2.196-98, italics mine).

Shakespeare thus distributes the components of female heroism between two characters. Although the destinies of both Desdemona and Emilia issue in martyrdom, their heroic styles are distinct. The waiting woman, subordinate in social status as well as integrity, at last courageously acknowledges and embraces through active conflict the contradictions of the status of wife that are inscribed in the heroics of marriage. The aristocratic Desdemona, on the other hand, dwindles, rather than grows, from a lively and courageous girl to a wife who is "half asleep," retreating with little choice to fragile explanations that subvert the basis of her marriage and to a naive, insistent, and unhelpful purity, and recovering her courage only in a final act of self-cancellation. ${ }^{126}$

Desdemona's unavoidable retreat to victimization, to passivity, and to the assumption of a kind of pre-marital chastity corresponds to Othello's final idealization of her as virginal, static, and inert. Removed from the heroics of marriage, she is also removed from action and conflict. The consignment of women and eros to inactivity is one of the solutions of the heroism of action. No longer distracted by the confusing, contradictory centrality that marriage has assumed in his identity, Othello ends his life by recalling his

126. Cf. Dash, pp. I03-30. 
military achievements and devotion to public service. Thus the beautiful, immobilized Desdemona combines with the neighing steed, the plumed troop, the spirit-stirring fife, the royal banner, and all quality, pride, pomp, and circumstance of glorious war to evoke with unarguable lyric beauty the tremendous elegiac power of the lost past.

\section{vi}

No Shakespearean tragedy focuses exclusively on a strong, central female figure. That in Othello Shakespeare should diffuse female heroism between two figures, distinguishing the sexual styles of waiting woman and lady, has significant implications for determining his interests, as well as for assessing the tragic representation of sexuality. Before turning to these crucial issues, however, I would like to introduce a comparison with The Duchess of Malfi (c. I6I3-I4), written approximately ten years after Othello. Here it suffices to note that it is, of course, Othello's heroism that assumes central importance in the earlier play. Although Shakespeare clearly recognizes and explores the potential for female heroism in the qualities inscribed in the Protestant idealization of marriage, he remains primarily concerned to examine the decline of the heroism of action by dramatizing its inadequacy when faced with the challenges of private life. In his next tragedy of love, Antony and Cleopatra ( 1607 ), rather than elaborating his insights into the contradictions inherent in marriage itself, he chooses instead to focus on the conflict between eros and public service, continuing his intense scrutiny of the tragic obsolescence of the epic-chivalric heroic style.

In The Duchess of Malfi the process of decline characterizing the representation of the heroism of action in Jacobean tragedy is already complete, its logic manifest. As in Othello, the distinction between public and private domains demands scrutiny and redefinition. Conflicts centered on these issues are initiated by an aristocratic woman's decision to disobey her male relatives and to marry a man not her social equal, thus def ying traditional social and sexual hierarchies and opening the way for their dissolution. But what is striking in comparing Othello and The Duchess of Malfi 


\section{The Expense of Spirit}

is less the similarity of the elements constituting each play than the differences with which they are emphasized and arranged. For example, in Othello the state is both rational and just; the hero's harmonious relationship with the state involves rewarded merit and dignified gratitude. In need of Othello's services and respecting his abilities, the political hierarchy of Venice easily accepts his unusual marriage. The complex psychological and sociocultural factors that combine to undo Othello do not stem from political absolutism, then, but are more subtle and diffuse.

The Duchess of Malfi also begins with a picture of the state as traditionally conceived by humanist idealism: governed by a rational prince with the aid of learned and truthful counsellors, setting an example of judiciousness for the people, and inspiring the nobility to virtuous action (I.I.5-23). ${ }^{127}$ But this idealized state is dislocated to France. It quickly becomes apparent that Italy, where the play takes place, has a decadent and corrupt court, dominated by a vicious, melancholy, and hypocritical Cardinal ("the spring in his face is nothing but the engendering of toads" [ I. I. I67-68]) and his pathological brother, Ferdinand ("a most perverse and turbulent nature; / What appears in him mirth is merely outside. / . . He speaks with others' tongues, and hears men's suits / With others' ears: will seem to sleep o'th'bench / Only to entrap offenders in their answers; / Dooms men to death by information. / Rewards by hearsay" [I.I.I79-85]). In a further perversion of the humanist political ideal, each brother surrounds himself with sycophants and "never pays debts, unless they be shrewd turns" (I.I.I9I). The profitable counsel to be exchanged between prince and advisers has degenerated into rigid, mindless, absolutism. "Methinks you that are courtiers should be my touchwood, take fire when I give fire; that is, laugh when I laugh, were the subject never so witty," advises Ferdinand, in one of his eeriest speeches (I.I.I27-30). Given the diseased nature of the state, how can its defense be valued? Military heroism is evoked only in brief allusions and associated with the Cardinal, Ferdinand, and their savage, discontented henchman, Bosola (e.g., I.I.76, 89-126; 3.3;

127. All references to The Duchess of Malfi, identified in the text by act, scene, and line numbers, are to Fraser and Rabkin, vol. 2, The Stuart Period, pp. $476-515$. 


\section{Heroics of Marriage in Renaissance Tragedy}

3.4). The steward Antonio's victories at games become nostalgic exercises, staged by servant courtiers for the amusement of their betters. "When shall we leave this sportive action, and fall to action indeed?" asks Ferdinand, disingenuously (I.I.92-93).

Webster is dramatizing an anachronistic neofeudal regime in the process of decline: in short, to use Lawrence Stone's terms, a crisis of the aristocracy. Though scholars have noted this fact, until a short time ago analyses have subordinated the political and sociocultural issues that generate conflict in the play to moral assessments of guilt and innocence: shall we blame the Duchess or praise her for courageously compromising the demands of her position in order to marry her steward for love? How shall we assess the guilt and latter-day conversion of the dangerous, tortured, victimized Bosola?-itself a question that leads to assessments of the relevance of the play's fifth act, from which the Duchess has disappeared. ${ }^{128}$ In a recent essay, however, Frank Whigham has forcefully redirected analysis, demonstrating that moral judgments of the characters are at best peripheral to an understanding of the play and locating the action precisely within Jacobean social processes. ${ }^{129}$

Whigham partially couches his arguments in the terms set down by Raymond Williams's conception of culture as a perpetually dynamic network of processes of change. In relation to a hegemonic dominant culture, Williams isolates several formative modes that "are significant both in themselves and in what they reveal of the characteristics of the "dominant." His notions of "residual" and "emergent" processes are most illuminating in terms of The Duchess. Williams defines the "residual" as a process by which a culture relates to the elements of its own past: "thus certain experiences, meanings, and values which cannot be ex-

I28. These questions indicate the principal directions of almost all of the scholarship on The Duchess of Malfi. Representative examples of different ways in which these issues are addressed include James L. Calderwood, "The Duchess of Malfi: Styles of Ceremony," Essays in Criticism, I2 (1962), I33-47; and Susan C. Baker, "The Static Protagonist in The Duchess of Malfi," Texas Studies in Literature and Language, vol. 22, no. 3 (Fall I980), 343-57.

I 29. Whigham, "Sexual and Social Mobility." Whigham's essay includes a good bibliography of criticism of the play. See also Margaret L. Mikesell, "Matrimony and Change in Webster's The Duchess of Malfi," Journal of the Rocky Mountain Medieval and Renaissance Association, 2 (January I98I), 97-I I I. 


\section{The Expense of Spirit}

pressed or substantially verified in terms of the dominant culture, are nevertheless lived and practiced on the basis of the residue... of some previous social and cultural institution or formation." Although this aspect of the residual can have an oppositional relation to the dominant culture, it is distinct from "that active manifestation of the residual . . . which has been wholly or largely incorporated into the dominant culture." Where the residual describes a culture's relation to its past, Williams's notion of "emergent" formations delineates a process by which a dominant culture confronts the present and future. "By emergent," he argues, "I mean ... that new meanings and values, new practices, new relationships and kinds of relationship are continually being created." 130

These concepts enable Whigham to explain mechanisms of cultural change that generate irreconcilable conflicts in The Duchess of Malfi. For example, he argues that Ferdinand is an embattled aristocrat, resisting an onslaught of upward mobility. Ferdinand's pathology is rooted in a residual exclusivity that now appears deranged, an obsessive pride in purity of blood that becomes the basis of an incestuous attachment to his sister. Antonio, on the other hand, participates in the (to Ferdinand) threatening emergent cultural forces. Whether Antonio's motives for marrying the Duchess are ambitious is arguable, but it is clear that his valuable skills are administrative rather than military; and that his managerial abilities match those that became increasingly important to upwardly mobile men in sixteenth-century England, men who sought and attained advancement at court through education and achievement, rather than assuming elite status as a birthright. The isolated, perplexed Bosola perceives the evil of the neofeudal regime of the Aragonian brothers but cannot imagine a place for himself within another political formation. A veteran soldier without an occupation in times of peace, the neglected henchman embodies the socioeconomic transition from a collectivist ethic of service to an ascribed aristocracy to a mobile bourgeois economy of wages, employment, and individualistic achievement. As

I30. Raymond Williams, Marxism and Literature (Oxford: Oxford University Press, 1977), pp. I22-23. 


\section{Heroics of Marriage in Renaissance Tragedy}

Whigham explains, Bosola, losing his belief in rank, finds himself caught between residual and emergent cultural modes:

As the human origin of rank was gradually revealed, it became clear that the power to confer it was freely available to those who could pull the strings of influence or purse. When ascriptive status emerged as a commodity, the king's sacred role as fount of identity began to decay, and with this shift came a change in the nature of identity itself. It became visible as something achieved, a human product contingent on wealth, connection, and labor. Later, when Marx described it theoretically, the notion could seem a conceptual liberation. . . . But in the Renaissance, when this insight began to be visible, it seemed a loss rather than a liberation. The obligation to found identity on one's actions seemed to sever the transindividual bonds that bound the polity together; it left one on one's own. 131

Although he is describing Bosola, Whigham provides in this passage a cogent analysis of the historical conditions that make female heroism possible in Renaissance tragedy. Bosola, himself of "base descent," remains enmeshed in an unholy and dependent alliance with the corrupt and anachronistic past embodied in Ferdinand; for him the glimpse of a possible future, though poignant, is belated and brief. Yet it is not Bosola but the Duchess herself who is the hero of the play, precisely because it is she who most fully embodies the "coincidence of loss and possibility" located in the shifts of cultural identity taking place in the Renaissance. ${ }^{132}$ Proud of her royal birth and stature, the widowed Duchess is also in love with her steward and determined to disobey her brothers, woo Antonio, and marry him. Thus she is caught between classes, between sexes, between tenses: as a young widow, she has a past and seeks a future; as an aristocrat who is also royal, she is independent, politically central, a ruler; but as a woman she is marginal, subordinate, and dependent-a status that her brothers' tyranny makes abundantly clear. With her conjoined, paradoxical attachments to present, future, and past, to status granted at birth as well

I3I. Whigham, "Sexual and Social Mobility," p. I77.

132. Ibid. 


\section{The Expense of Spirit}

as status gained by achievement, to female independence and female subordination, the Duchess is in a position as fluid and anomalous as the social conditions of Jacobean England. Viewed in this context, it becomes clear why Webster chooses an aristocratic woman as the figure that could represent most fully the irreconcilable conflicts of tragedy.

Understanding the play's class and sexual conflicts in terms of emergent and residual cultural modes allows us to connect the two dominant types of Renaissance sexual discourse examined in this book more firmly with historical process, with the shifting relations among present, past, and future, than is possible to do when exploring Othello. Specifically, the polarizing mentality that idealizes or degrades women and eros is associated in the play with the decadent, tyrannical Ferdinand and the alienated, paralyzed Bosola. As Whigham shows, Ferdinand's obsessive attachment to his sister constitutes not a desire for sexual union, but a deranged purity, in which her absolute chastity becomes the equivalent of his exclusivist, aristocratic territoriality. ${ }^{133}$ In his narcissistic identification with the Duchess as his twin, he insists that she remain unmarried, her life sexless. "And women like that part, which, like the lamprey, / Hath never a bone in't," he warns obscenely (I.I.343-44). ${ }^{134}$ Ferdinand's association of sex with pollution is echoed by Bosola's misogyny, which is second only to Truewit's in its nauseated specificity and is distinct in intensity from that of the comic wit only by being completely gratuitous. "I would sooner eat a dead pigeon, taken from the soles of the feet of one sick of the plague, than kiss one of you fasting," Bosola tells an old lady, who at first appears to enter the play for the sole purpose of being abused by him (2.1.44-46). ${ }^{135}$ The other character who

I33. Whigham, "Sexual and Social Mobility," pp. I69-7I.

I34. For a discussion of erotic imagery in the play, see Dale Randall, "The Rank and Earthy Background of Certain Physical Symbols in The Duchess of Malfi," Renaissance Drama, N.S. I 8 (1987).

I35. Actually, like the character Julia, the Cardinal's mistress, the old lady seems to be in the play as a comment on and warning about the Duchess's marriage. Her odd appearances (see also 2.2.1-27) can be linked with the complex of witch imagery that pervades the play (see, e.g., 3.I.78, 3.2. I40$4 \mathrm{I}, 3.4 .57-58$, and 3.5.54-55) and the misogynistic connections of the Duchess with the lady-of-pleasure tradition, traced by Randall. 


\section{Heroics of Marriage in Renaissance Tragedy}

associates the Duchess with absolute purity is Antonio, who, in his role as obedient steward at the beginning of the play, construes her as divine, an unattainable ideal, associated with rebirth, an exception to her sex:

Whilst she speaks,

She throws upon a man so sweet a look

That it were able to raise one to a galliard

That lay in a dead palsy; and to dote

On that sweet countenance: but in that look

There speaketh so divine a continence

As cut off all lascivious and vain hope.

Her days are practiced in such noble virtue

That, sure her nights, nay more, her very sleeps,

Are more in heaven than other ladies' shrifts.

$$
\text { [I.I.205-I3] }
$$

The Duchess recognizes her brother's grotesque misogyny and Antonio's rapturous idealization as equally life-denying; indeed, she resists the dualizing sexual sensibility that would relegate her to aestheticized inactivity and permanent widowhood in terms and imagery that recall the destinies of Zenocrate and Desdemona. "Why should only I, / Of all the other princes of the world / Be cased up, like a holy relic? I have youth, / And a little beauty," she protests to Ferdinand (3.2.137-40). And she exhorts Antonio to marry her by resisting in a similar vein immobilization as an icon, associating the widow's enforced chastity with stasis and death: "This is flesh, and blood, sir, / 'Tis not the figure cut in alabaster / Kneels at my husband's tomb" (I.I.459-6I). ${ }^{136}$

Much of the scholarly debate about the Duchess's actions has centered on her sexuality. She has been blamed for being irresponsible, overly passionate, too bold, in analyses that of ten focus on the demands of her social position and/or on the conservative body of Renaissance thought that regarded a widow's remarriage as lustful and disloyal. Or she is praised for being both courageous and nurturing, in analyses that often pit the individual against society and, in post-romantic terms, privilege the former while

I36. Cf. Othello, 5.2.3-5: "Yet I'll not shed her blood, / Nor scar that whiter skin of hers than snow, / And smooth, as monumental alabaster." 


\section{The Expense of Spirit}

regarding the latter as oppressive. ${ }^{137}$ In order to escape these terms, Whigham rejects entirely an analytic focus on the erotic, which he regards as moralistic and trivial: “the Duchess's actions should be seen not as erotic (a common male reduction of women's issues) but as political," he insists. ${ }^{138}$

Yet to view eros as a comparatively trivial, nonpolitical issue is also to miss the point. The Duchess repeatedly emphasizes her sexuality, indicating in precise and definite terms its centrality to her identity ("This is flesh, and blood, sir . .."). Throughout the play Webster not only stresses the strength of her desire for Antonio, but also focuses on her pregnancies, her erotic playfulness, and her tender, nurturing motherhood. "I pray thee look thou givest my little boy / Some syrup for his cold, and let the girl / Say her prayers ere she sleep," she instructs her waiting-woman at the moment of her death (4.2.203-5). ${ }^{139}$ The Duchess's erotic identity, then, is omnipresent in the play and central to it. The point is not that erotic issues are separate from, and/or less important than, political ones; to adopt this position is to accept the sexual stance of Bacon, Donne, Tamburlaine, Othello, and-what is decidedly less appealing - of Ferdinand. As we have seen, this point of view does not adequately account for the number of great Jacobean tragedies that center on private experience. Rather than representing public and private life as a hierarchy that subordinates the latter to the former, The Duchess of Malfi attempts to draw the two domains together and to confer upon them equal distinction. The point is a crucial one, because in this play, unlike Othello, the effort constitutes a central, rather than a subordinate action, and its failure provides the primary tragic material of the play.

The effort to unite public and private life and to confer upon them equal prestige is formulated in the Protestant idealization of marriage. This is the discourse in which the Duchess is inscribed. As we have seen, in the Protestant conception of marriage as a

I37. See, e.g., Calderwood; and Baker.

I 38. Whigham, "Sexual and Social Mobility," p. I 84.

I39. See Alan Dessen, "Modern Productions and the Elizabethan Scholar," Renaissance Drama, n.s. (1987); Dessen points out the ways in which excluding these lines from a production of the play, as was done in the recent National Theatre production ( $1985-86)$, tends to alter the audience's view of the Duchess and to reduce the complexity of her character. 


\section{Heroics of Marriage in Renaissance Tragedy}

heroic endeavor, a military idiom is absorbed and transformed from the heroism of action, and this idiom, though sometimes applied exclusively to males, frequently ignores gender or explicitly includes women as subjects. It is precisely this military vocabulary of conquest and defeat that the Duchess uses to define her marriage to her steward. In response to her brothers' demand that she remain widowed, for example, she reflects:

Shall this move me? If all my royal kindred Lay in my way unto this marriage, I'ld make them my low foot-steps. And even now, Even in this hate, as men in some great battles By apprehending danger, have achieved Almost impossible actions: I have heard soldiers say soSo I, through frights and threatenings, will assay

This dangerous venture. Let old wives report I winked, and chose a husband.

$$
\text { [I. I.348-56] }
$$

"My laurel is all withered," she says, characterizing her eventual defeat; and she adds, "I am armed 'gainst misery" (3.5.90, I4I). Finally, the Duchess's conception of her marriage as a dangerous but necessary venture also takes on the lonely, absolutist commitment shared by the tragic hero and the hero of marriage ("I am going into a wilderness, / Where I shall find nor path, nor friendly clue / To be my guide" [I.I.367-68]), leading her inevitably to ponder her own condition in universal terms, as Desdemona never could, and to her prolonged encounter with death. It has been argued correctly that the Duchess's confrontation with "ultimate universal hostilities" distinguishes her as "the first fully tragic woman in Renaissance drama." 140 I would add to this crucial point that it is the full recognition of the importance of private life, here claiming equal status with public concerns, that makes her tragic stature possible; in turn, the Duchess's heroism helps to define and clarify the heroics of marriage.

It has also been argued that the Duchess's metaphysical confrontation with the foundations of human identity contains "the kind of speculation familiar from Shakespearean tragedy, where the ele-

I40. Whigham, "Sexual and Social Mobility," p. I74. 


\section{The Expense of Spirit}

vated are crushed as they inaugurate new conceptual options."141 Despite her disclaimers to Ferdinand ("Why might not I marry? / I have not gone about, in this, to create / Any new world, or custom" [3.2.1 I0-27]), this argument continues, the Duchess is in fact thoroughly committed to constructing a revolutionary future, viewing herself, like Tamburlaine, as a pioneer who will ignore traditional class barriers and chart a course through the wilderness to discover and colonize a new world, disdainful of the past and independent of it. ${ }^{142}$ "All her particular worth grows to this sum: / She stains the time past; lights the time to come," says Antonio; and keeping social history in mind, we can recall that this observation reflects the hopes of a steward who, whether he achieves greatness or has it thrust upon him, unquestionably becomes a protagonist of upward mobility in the play (I.I.2 I 8-I9).

How revolutionary is the Duchess? Her assertiveness in wooing Antonio has been characterized as androgynous, an attempt to conjoin male and female modes. ${ }^{143}$ This idea can lead us to compare the behavior of the Duchess and that of the disguised female comic hero, whose androgyny gives her the freedom actively to pursue her mate. As discussed earlier in this study, the female comic hero's androgynous disguise exists in a holiday world over which she reigns, but the holiday world functions solely to renew and perpetuate the orderly world of every day. At the end of a romantic comedy, therefore, the festive world is left behind; the female hero, who has been free from sexual constraint throughout the play, surrenders her disguise along with her control, in a gesture of commitment to her future as an obedient, subordinate wife. In romantic comedy the contradictions between the woman's present freedom and her future constraint are contained in the final, harmonious, comic focus on the present.

I4 I. Whigham, "Sexual and Social Mobility," p. I74.

I42. Cf. Berggren, p. 353; and Whigham, "Sexual and Social Mobility," p. 172 .

I 43. See, e.g., Lois E. Bueler, "Webster's Excellent Hyena," Philological Quarterly, 59 (1980), I07-II. Bueler provides a fascinating account of the associations of sexual ambiguity with the hyena, alluding to Ferdinand's pathological fantasies of his sister's sexual relations: "Methinks I see her laughing - / Excellent hyena! - talk to me somewhat, quickly, / Or my imagination will carry me / To see her, in the shameful act of $\sin ^{\prime \prime}(2.4 \cdot 38-4 \mathrm{I})$. Also see 3.2.222 for an intriguing reference to Antonio as a hermaphrodite. 


\section{Heroics of Marriage in Renaissance Tragedy}

In The Duchess of Malfi the Duchess's widowhood, with its temporary and limited freedoms, can be viewed in aesthetic terms as the symbolic equivalent of an androgynous disguise. Unlike a married woman, a widow in Renaissance England had a distinct legal capacity that she was progressively consolidating in the late sixteenth century, and unlike a single woman, she had an acknowledged right to choose her own mate. Just as the female comic hero does, the widowed Duchess identifies her future mate and follows eros into an alternative world. But as scholars have demonstrated, the widow's freedom constituted an anomaly that was difficult for Jacobean culture to absorb. On the one hand, an independent woman running her own household presented a contradiction to English patriarchal ideology; on the other, a widow who did remarry was criticized as lustful and disloyal, particularly in the threat her remarriage posed to a family's retention of property. ${ }^{144}$

Like Moll Frith's male clothes, then, the Duchess's widowhood calls attention to the irreconcilable contradictions in Jacobean sexual values. But while, unlike the female hero of romantic comedy, Moll refuses to surrender her clothes, she also removes herself from participating in marriage. Thus her androgyny does not constitute a radical threat to the existing social structure. In contrast, the Duchess both marries and attempts to remain independent from the dominant culture, conceptualizing her marriage as autonomous: "All discord, without this circumference / Is only to be pitied and not feared" (I.I.472-73). There is, of course, no place within the absolutist state of the Aragonian brothers to absorb and contain the Duchess's unusual marriage. The vision of the future cannot be amalgamated, put off, or distanced, as it can in a comic structure. In tragedy the future has arrived, and it is unquestionably violent, revolutionary.

Webster, then, clearly recognizes the radical potential of female heroism in the process of cultural change. From this perspective, distinct conceptual alliances and antitheses begin to take shape in our consideration of the play. The dualizing mentality that either idealizes or degrades women and eros becomes associated with an embattled and declining aristocracy, tyrannical political absolutism, an obsolete heroism of action, a receding past. In contrast, the

I44. See Todd, esp. p. 73. 


\section{The Expense of Spirit}

heroics of marriage is associated with the bourgeois recognition of merit in determining status, rather than the aristocratic reliance on birth; with administrative rather than military skill; with upward social mobility and female independence; an impending future.

Yet the Duchess's identity and greatness-her heroism-are grounded in the past as well as projected into the future. Though on one level the dichotomy between a corrupt and decadent past and a more promising future is confidently formulated and supported in the play, on another the relation between past and future emerges in contrast as one of conflicting loyalties between two worthwhile modes of thought and being. This second, more subtle, syndrome, which assigns not only corrupt power but sympathy and value to the past, can be perceived by locating the Duchess precisely within the heroics of marriage, the discourse that she creates and adheres to and that defines her.

Like Desdemona, the Duchess is forced to defy male relatives (i.e., authorities) in order to marry the man she wants. Again like Desdemona, she becomes embroiled in the contradictory injunctions of the idealization of marriage that both do and do not encourage woman to have a say in selecting her spouse and do and do not demand familial consent to a match. Yet while Shakespeare dramatizes this issue as a subtle and significant but subordinate theme, Webster brings it to the very center of the action, embodying its consequences in the career of a female hero whose private life subverts the established order. Although Desdemona's marriage matters to the established political order, its primary public importance rests in the state's need for her husband's services; her elopement with Othello precedes the action and takes place offstage. In contrast, the Duchess is a ruler; it is her marriage that has crucial importance to the state and shakes its foundations, a fact that, conjoined with her brothers' tyranny, makes the radicalism of her action at once more apparent and more urgent than that of Desdemona. Because the marriage between the Duchess and Antonio is fully dramatized on stage, the ambivalences conjoining family consent and female independence, which are reduced in Othello to the receding residue of Brabantio's displeasure, constitute the major, irresolvable, tragic conflicts in the later play. The Duchess and Antonio's marriage contract per verba de presenti itself has an ambiguous status. As historians have demonstrated, clan- 


\section{Heroics of Marriage in Renaissance Tragedy}

destine marriage, or vows made between consenting adults with a witness present, constituted a perfectly legal union in England until marriage laws were clarified in the eighteenth century. But the social status of such a marriage, contracted without banns, solemnized outside the church, and associated with both poverty and illicit sexual activity, was at best marginal. ${ }^{145}$ All throughout her wedding ceremony, the Duchess both abjures and affirms the need for legitimating institutions and traditions, thus unwittingly emphasizing the problematic vulnerability of her marriage. Citing the legality of the ceremony, she demands, "What can the Church force more?" adding insistently, "How can the Church build faster? / We now are man and wife, and 'tis the Church / That must but echo this" (I.I.489, 493-95). Later, when Ferdinand calls her children bastards, the Duchess counters angrily, "You violate a sacrament o'th'Church / Shall make you howl in hell for ' $t$ " (3.5.39-40).

But the most powerful contradictions that work to undermine the Duchess's marriage are those centered on status and rank. Though the inequalities that separate Othello and Desdemona (the Moor's age and blackness) are profound, they are nevertheless sufficiently intangible to be easily absorbed by the state: the marriage challenges prejudice, rather than established, class-based social and political hierarchy. ${ }^{146}$ In contrast, the discrepancies in rank between the Duchess and Antonio comprise officially institutionalized boundaries, not to be crossed: "Of love, or marriage, between her and me, / They never dream of," Antonio realizes (3. I.36-37), referring not only to the ruling elite, but to the rest of the populace as well. By locating the foundation of identity in merit rather than birth, then, the Duchess drives a radical, irreconcilable wedge between the natural and social orders, previously regarded as identical. "If you will know where breathes a complete man, / I speak it without flattery," she tells Antonio, "turn your eyes, / And progress through yourself" (I. I.440-42).

Yet the Duchess does not adhere entirely to this commitment to

I45. See Stone, Family, Sex and Marriage, pp. 35, 31 7, 629.

I46. Interestingly, Othello justifies his marriage to Desdemona by alluding to his royal birth as well as his personal merit: "I fetch my life and being / From men of royal siege, and my demerits / May speak unbonneted to as proud a fortune / As this that I have reach'd" (I.2.2I-4). 


\section{The Expense of Spirit}

achieved rather than ascribed status. Although the greatest obstacles to her marriage take the form of the brothers' tyranny, an external impediment, it is important to note the extent to which the Duchess herself continues to rely on her royal birth. It is not simply that she takes the lead in the wedding scene ("The misery of us, that are born great, / We are forced to woo because none dare woo us" [I.I.445-46]); she also delivers a very mixed message on the question of rank. Thus she defines Antonio as a "complete man" and claims to "put off all vain ceremony," begging to be regarded not as a royal Duchess, but merely as "a young widow / That claims you for her husband" (I.I.460-62). At the same time, however, she reminds him "what a wealthy mine / I make you lord of" and adds, in what is probably the clearest example of the double bind created by her superior power, "Being now my steward, here upon your lips / I sign your Quietus est. This you should have begged now" (I. I.434-35, 467-68). As is often observed, the Duchess continues to take the lead throughout the play, whereas Antonio repeatedly demonstrates his helpless inability either to confront the dreaded brothers or to outwit their villainy: "I am lost in amazement: I know not what to think on 't," he says at one point, in what could stand as a summary statement of his position (2. I. I 82). ${ }^{147}$

Based in a problematic awareness of a wife's possible social superiority to her husband, the perception of a potentially severed relation between hierarchies of gender and power is also a central issue in the heroics of marriage. "But yet when it hapeneth, that a man marrieth a woman of so high a birth, he ought (not forgetting that hee is her husband) more to honour and esteeme of her, than

I47. Cf. Whigham, "Sexual and Social Mobility," p. I76. Whigham remarks of Antonio that "he agreed to his wife's coercive marriage proposal with the def erence of the subordinate he feels himself to be." Whigham notes several instances of Antonio's inability to keep up with the aristocratic world he has furtively and reluctantly embraced, including his remaining in hiding when Ferdinand approaches his wife with a dagger (3.2) and, finally, his futile journey in Act 5, when he attempts a reconciliation with the Aaragonian brothers: "Antonio's final action, the desperately naive journey to the Cardinal for reconciliation, freezes him for us, as one whose unsought elevation never brought much sense of how to navigate the webs of alliance and enmity." 


\section{Heroics of Marriage in Renaissance Tragedy}

of his equall, or of one of meaner parentage, and not onely to account her his companion in loue, and in his life, but (in diuers actions of publike apparance) to hold her his superior," advise Dod and Cleaver. Yet they contradict themselves by adding, "She ought to consider, that no distinction or difference of birth and nobility can be so great, but that the league which both Gods ordinance and nature hath ordained betwixt men and women, farre exceedeth it: for by nature women was made man's subiect." 148 What bond is more "natural," birth or marriage? Dod and Cleaver lean toward the radical position of granting greater importance to marriage, but continue perplexed. Their perception of the problem, which comes from the thwarted attempt to unite not only gender and power, but public and private domains, is itself subversive, but it remains unresolved and, as such, sheds light on The Duchess of Malfi. "You are a lord of mis-rule," the Duchess teases Antonio, who counters playfully, "My rule is only in the night" (3.I.6-8). The fact that their marriage must remain exclusively privatewithin "this circumference"-does indeed become the sign of its doom.

The contradictions about rank, status, gender, and power that characterize the heroics of marriage perpetuate rather than resolve the conflicts between past and future. At the moment of the Duchess's death, the irreconcilable loyalties that are the source of tragic conflict become most clearly visible. On the one hand, the Duchess's rank plays a central role in the construction of her tragic heroism. "For know, whether I am doomed to live, or die, / I can do both like a prince," she tells Ferdinand (3.2.70-7I). Later, when Bosola confronts her with chaos and destruction, she asserts her identity in the play's most famous line, "I am Duchess of Malfi still" (4.2. I42). The Duchess's courage and dignity in facing death are indissolubly conjoined with her royal stature. On the other hand, the sociopolitical conditions that make heroism possible in the play unquestionably reside in the decay of and need to defy the order from which her stature derives. Antonio correctly defines the heroic response to the resulting untenable position as one of active, chosen suffering: "Though in our miseries fortunes have a

148. Dod and Cleaver (I630), sigs. $\mathrm{K}$ and $\mathrm{K}^{\mathrm{v}}$. 


\section{The Expense of Spirit}

part / Yet in our noble sufferings she hath none: / Contempt of pain, that we may call our own" (5.3.55-57).

As I have tried to show, with its background in stoicism, religious martyrdom, and medieval treatises on the art of dying, the heroism of endurance that Antonio defines is connected in Protestant moral treatises with the idealization of marriage and the elevation of the private life, a combination of elements particularly amenable to the construction of female heroism. Much recent scholarship has demonstrated that unstable social conditions often generate female heroism and creativity, which in turn play a major role both in demolishing an old order and in constructing a future. ${ }^{149}$ In this context, an interesting example of Shakespeare's relative conservatism in representing women emerges from contrasting the Duchess's death with Desdemona's. The two scenes offer a remarkable instance of a reverse parallel. Both women are unjustly strangled for misconceived sexual crimes; both die martyr's deaths, accompanied by loyal and loving waiting women. As we have seen, Desdemona's understanding of her own situation, along with her responsibility for it, recedes throughout Othello. At the moment of her murder, she begs for her life, an action that, however sensible it may appear in isolation, is definitely not characteristic of a tragic hero. Desdemona's final act is one of selfcancellation; courageous self-assertion is instead assigned to the waiting woman, Emilia, who is given the noble lines: "Thou hast not half the power to do me harm / As I have to be hurt" (5.2. I6364). By distributing the components of female heroism between the two women, Shakespeare confers independent selfhood on the subordinate character, while merging Desdemona's identity entirely with Othello's. Thus the stage is cleared for Othello's final, climactic consideration of his own, more active heroism, and the focus centers entirely on the lost past. The emphases in the Duch-

I 49. See Rose, "Gender, Genre, and History"; Lamb; and Schulenburg. See also Penny Schine Gold, The Lady and the Virgin: Image, Attitude, and Experience in Twelfth-Century France (Chicago: University of Chicago Press, 1985). For a very interesting treatment of female heroism in Restoration and eighteenth-century tragedy, see Laura Brown, "The Defenseless Woman and the Development of English Tragedy," Studies in English Literature, 22 (1982), 429-43. 


\section{Heroics of Marriage in Renaissance Tragedy}

ess's death scene are, of course, different. The most prolonged moment in the play, the Duchess's death is made to carry the full burden of tragic significance, as her debates with Bosola on the meaning of life and the effects of her death on the other characters make clear. Summoning all her princely dignity, the Duchess also dies thinking of her children's welfare, thus dissolving the distinction between "woman" and "greatness" that her waiting woman, Cariola, makes after her marriage (I.I.505). The Duchess's dual role as agent and sacrifice is never simplified to an emphasis on her victimization. Instead, her courage in facing death is emphasized ("Pull, and pull strongly, for your able strength / Must pull down heaven upon me," [4.2.230-3I]), along with her acceptance of responsibility for her own actions. "Doth not death fright you," asks Bosola. "Who would be afraid on 't?" she replies, "Knowing to meet such excellent company / In th' other world" (4.2.2 I I-I4). A final contrast occurs when Cariola provides a foil to the Duchess's heroism by begging for her life, the exact reverse of the situation in Othello (4.2.23 I-55).

Despite the Duchess's greater prominence, however, she is assigned precisely the same fate as Desdemona and, for that matter, Zenocrate: she is removed from the active resolution of the conflicts of the play and granted instead the indirect role of inspiration. In one critic's useful terms, she ceases to be the maker, and becomes instead the bearer, of meaning. ${ }^{150} \mathrm{~A}$ varied range of crucial activities occupies the stage for an entire act after the Duchess's murder, when, like Desdemona, she returns from the dead as a disembodied voice, an echo and "thing of sorrow" meant to protect her husband $(5 \cdot 3.24)$. In order to clarify her permanent status as an unattainable ideal, Webster specifically constructs her death as a work of art, relegating her value to the state of bodiless, aestheticized inactivity that she had heroically resisted in life: "This is flesh, and blood, sir, / 'Tis not the figure cut in alabaster / Kneels at my husband's tomb" (I.I.459-6I). "Who do I look like now?" she asks Cariola in preparation for her death. "Like to your picture

I so. Laura Mulvey, quoted in Nancy J. Vickers, "Diana Described: Scattered Woman and Scattered Rhyme," in Writing and Sexual Difference, ed. Elizabeth Abel (Chicago: University of Chicago Press, I980), p. I09. 
in the gallery, / A deal of life in show, but none in practice; / Or rather like some reverend monument / Whose ruins are even pitied." "Very proper," replies the Duchess, ready now for death (4.2.30-35).

As the hero of the play the Duchess embodies its major conflicts; thus in order to remove her from their active resolution, Webster has had, as it were, to rewrite her part. The Duchess is inscribed in the heroics of marriage, a discourse that inevitably breaks down from a combination of external opposition and its own internal contradictions, which emerge as an irresolvable conflict of loyalties between future and past. At the end of the play, Webster resolves the conflict by discarding the future and reinscribing the Duchess in the dualistic discourse that idealizes (or degrades) women, thus placing her above and beyond the action, in a position that she, pursuing the future, had specifically resisted and that is unambiguously associated in the play with death and the disappearing past. As Bosola seeks to avenge her murder and the Cardinal and Ferdinand die, leaving "no more fame behind 'em than should one / Fall in a frost, and leave his print in snow" (5.5.114-I5), the associations of the past with pathology and corruption also recede, while the dead Duchess's elegiac role assumes greater prominence. Viewed in the context of the polarizing sexual discourse that defines her final position, the construction of the Duchess's death can be seen as reactionary: she is removed from the potentially radical conflicts of the heroics of marriage that have fully defined her, and the sympathy and value assigned to her life are unambiguously allied instead with a compelling tribute to the lost past.

\section{vii}

Webster's removal of the hero from the last act of the play is so striking and bold a move that it raises important questions about the nature of English Renaissance tragedy. Indeed, given its pointed critique of political absolutism (the form of government favored, if not enacted, by James I), its recognition of the centrality of the private life, and its profound exploration of female heroism, The Duchess of Malfi becomes an excellent text from which to assess the nature and extent of radicalism in Jacobean tragedy. By 


\section{Heroics of Marriage in Renaissance Tragedy}

embodying major tragic stature exclusively in a woman, Webster acknowledges the female hero's pivotal role in the process of historical change, exploring the workings of the contradictory components of female identity in Renaissance sexual ideology as Shakespeare never does. ${ }^{151}$ Recalling the comparison between Tamburlaine's revolutionary career and the Duchess's role as a social pioneer who courageously disregards traditional class and rank barriers, one can perceive the impossibility of finding either figure in Shakespeare's plays, where shepherds who gain power turn out to be princes in disguise; and powerful, central women preside exclusively over the comic world, not the more elevated and prestigious tragic one. The figures of Malvolio and Antonio provide a similarly telling contrast. A Renaissance playwright creating an upwardly mobile steward clearly had options in his representation of that figure. Should he be a pompous ass, a vain, deluded buffoon, easily outwitted and finally expelled by the aristocracy? Or should he be able, competent, appealing and, if perhaps also mediocre, nevertheless aware of his own limitations and capable of winning a Duchess's love?

My purpose in making these comparisons is not to find fault with Shakespeare, but to point out that, given the variety of conceptual options available in Jacobean culture, he often chooses the conservative ones, a pattern that becomes obvious when we view him not on his own, but in relation to his fellow playwrights. Because Shakespeare is indisputably the greatest writer of English tragedy, his conservatism relative to his contemporaries should have a great deal to tell us about the nature and purposes of that form of drama. Despite Webster's considerably greater interest in, and sympathy for the future, for example, he nevertheless ends The Duchess of Malfi by diminishing the future and paying a powerful tribute to the past. Recent scholarship concerned with the

I SI. I do not regard Shakespeare's Cleopatra as an exception to this observation. Arguably, Antony and Cleopatra moves beyond tragedy and into romance. Certainly Cleopatra's "infinite variety" is unique, not characteristic; rather than embodying the contradictions of Renaissance sexual ideology, which becomes the central focus of the play, she provides an alternative ethos that is opposed to the public/political world: i.e., the conflict is between love and duty. Finally, Cleopatra is not the sole hero of her play, as Lear, Hamlet, Macbeth, Othello, Coriolanus, and the Duchess of Malfi are of theirs. 


\section{The Expense of Spirit}

relation of tragedy to history has emphasized the foundations of tragedy in the failures of the past. ${ }^{152} \mathrm{~W}$ ith its relentless, subversive scrutiny of obsolete modes of heroism, tyrannical forms of government, unjust social systems, and inadequate sexual ideologies, tragedy is seen to play a radical role of negation, to clear the way for a new order by participating in the dissolution of archaic cultural formations. Not only has this scholarship rescued Renaissance drama from being assessed in terms of a nonreflective identification with the construct of unified hierarchy known as the "Elizabethan world picture"; it has also been invaluable in calling attention to tragic discourse as an historical process that plays a crucial role in the course of cultural change. But in correctly emphasizing the function of tragedy as a social critique, these analyses have tended to assume that the tragic exposé of social injustice is more real than the focus on loss and death, thus underestimating tragedy's considerable allegiance to the past. As Webster's elegiac conception of the Duchess's death makes clear, no matter how pronounced the criticism of the past and sympathy for the future may be in a play, the separation between past and future that is the defining purpose of radicalism never occurs within Jacobean tragedy. Instead, attention is focused on the radical act as one of sacrifice and extinction, and the future is diminished in deference to the past: "We that are young / Shall never see so much, nor live so long." 153 In this context Jacobean tragedy can be viewed not as

I 52. See especially Jonathan Dollimore, Radical Tragedy: Religion, Ideology and Power in the Drama of Shakespeare and His Contemporaries (Chicago: University of Chicago Press, I 984); Franco Moretti, “'A Huge Eclipse': Tragic Form and the Deconsecration of Sovereignty," in The Power of Forms in the English Renaissance, ed. Stephen Greenblatt (Norman, Okla.: Pilgrim, I982), pp. 740; Whigham, "Social and Sexual Mobility"; Cohen; and Heinemann. For other scholars who have addressed the issue of subversion and authority in Tudor-Stuart drama, see Greenblatt, Renaissance Self-Fashioning, esp. pp. I93254, and "Invisible Bullets: Renaissance Authority and Its Subversion," in Political Shakespeare: New Essays in Cultural Materialism, ed. Jonathan Dollimore and Alan Sinfield (Manchester: Manchester University Press, 1985), pp. I 8-47; and Montrose, "'Shaping Fantasies."

I 53 . I owe this point to Frye, who, quoting these lines, which are the last two lines of King Lear, comments (p. 6) that in Shakespeare the social contract that forms at the end of a tragedy is always a diminishment of the present and future: "the heroic and infinite have been; the human and finite are." 


\section{Heroics of Marriage in Renaissance Tragedy}

radical, but as conservative and nostalgic: a lament for a lost past from the point of view of the aristocracy. Seventeenth-century English tragedy tended increasingly to become a predominantly aristocratic form.

How can we reconcile the evident radicalism of Jacobean tragedy with its equally compelling nostalgia? As is well known, great tragedy, unlike comedy, has erupted in Western history in infrequent, irregular bursts, particularly in fifth-century Athens and sixteenth- and seventeenth-century Europe. Attempting to account for tragedy's simultaneous alliance with the past and future, Timothy J. Reiss has joined other scholars in pointing out that in each of its major appearances, tragedy has accompanied the rupture of a familiar order, in which "the essential relationships between physical, social, and religious life are now losing their reference to any 'experience of totality." At the same time, however, in both ancient Greece and Renaissance Europe, the major developments in tragedy coincide with the rise of science, the struggle to realize an emergent rationality for which analytic, referential knowledge, rather than mystery and mythical thinking, becomes "the true expression of reality." Reiss argues that during this process of change, "a sense of injustice appears, compounded of ignorance, fear, unfulfilled desire, and suffering, the mark of an 'absence' which of necessity escapes organization"-that is, meaninglessness. The function of tragedy is not simply to represent irreconcilable ambiguity, suffering, and injustice, but also to contain these ruptures precisely by defining them, giving them meaning and form. Tragedy's unique role in this process is to underline the moment at which the previously meaningless becomes legible and articulate, what Reiss describes as "the moment of accession to referentiality." Whereas other discourses (e.g., history) "take for granted the possibility of a discursive ordering of chaos, of the as-yet unknown . . tragedy performs the overcoming of that 'absence," "the enclosure of meaninglessness that "disappears as the very consequence of its naming." Reiss also emphasizes a dislocation between the protagonist and spectator of a tragedy. The protagonist is active but blind or, in the terms of this book, trapped in the past; the spectator, on the other hand, becomes conscious of a capacity to organize and to know, to create a future: "the discourse of tragedy may be ambiguous internally, but that is 
just the point: it is an ordered and enclosed ambiguity. . . . It presupposes a knowledge." By clearly defining and finally immobilizing the destructive ambiguities of suffering and injustice, then, tragedy provides an affirmation that a future imposition of order is possible. ${ }^{154}$

As Reiss makes clear, once tragedy has performed its function in the processes of cultural change, tragic plays may continue to be written, but no further development takes place within the genre. As he recognizes, these conceptions take different forms when embedded concretely in distinctive cultural situations. Reiss's formulations thus become particularly helpful for understanding the changing representation of love and sexuality in English Renaissance tragedy. As we have seen by examining Tamburlaine, in Elizabethan tragedy, created during a period of relative patriotism and optimism, the private life plays a marginal role in the representation of a heroism of action, to which it is at best subordinate, at worst destructive. In this context love and sexuality are constructed from a dualizing perspective that either idealizes or degrades women and eros, removing them from the significant center of action. Such a perspective of course lingers as a conceptual option in our culture, and as John Donne's marriage sermons, written between about I620 and I630, make clear, it remains prominent in Jacobean and Caroline England. Although this dualistic sensibility is never superseded, during the late sixteenth and early seventeenth centuries it gradually recedes before the Protestant idealization of marriage, a more multifaceted sexual discourse that elevates the private life and grants greater centrality to women as necessary protagonists in its enactment. Conjoined with a complex of sociocultural factors, including both the absolutism and pacifism of the king and the attempt to halt and consolidate the social mobility of the sixteenth century, the heroics of marriage becomes the primary subject of Jacobean tragedy. While Othello dramatizes the beginnings of this process by scrutinizing the de-

I 54. Timothy J. Reiss, Tragedy and Truth: Studies in the Development of a Renaissance and Neoclassical Discourse (New Haven, Conn.: Yale University Press, I980), pp. 19, 36, 20, 2I (italics his), 24, 35 (see, in general, pp. I-39). On p. 36 he remarks that "the reaction to tragedy ... would be at once the fear of a lack of all order and the pleasure at seeing such lack overcome." 


\section{Heroics of Marriage in Renaissance Tragedy}

cline of the heroism of action, The Duchess of Malfi manifests its logic completely by granting full attention and distinction to the private life and making visible the pivotal role of the female hero in the process of cultural change. During the development of Jacobean tragedy, the dualizing sexual discourse becomes associated with the disappearing past, the heroics of marriage with the promise of the future. But, as we have seen, the heroics of marriage breaks down, both from external (and reactionary) opposition and from its own unresolved contradictions. As these ambiguities assume greater centrality in tragic representation, they are immobilized within a final, elegiac tribute to the lost past, a process of containment clarified in the deaths of Desdemona and the Duchess of Malfi. In this way tragedy serves its complex function of articulating the need for a future by destroying the past and then mourning its disappearance. Once again this point becomes clear from examining the tragic representation of sexuality, in which no further development takes place. Either the scrutiny of the private life becomes increasingly involuted, focusing on corruption and extremes, as in the depictions of female villainy and incest in The Changeling (1622) and 'Tis Pity She's a Whore (I629); or the portrayal of endurance and suffering becomes increasingly static, as in The Broken Heart (I629). Fresh impulses in the development of the English drama are no longer articulated in tragedy, but in a less demanding and idealistic form, tragicomedy. 